\title{
Simultaneous isolation of gallotannins and a related phenolic from Mangifera indica kernels and assessment of their anti-Trichomonas vaginalis activities
}

\author{
Mohamed A. A. Orabi ${ }^{1 *}$, Soad A. L. Bayoumi², Hanaa M. Sayed², Enas A. M. Huseein³, Amgad I.M. Khedr', \\ Tsutomu Hatano ${ }^{5}$ \\ ${ }^{1}$ Department of Pharmacognosy, Faculty of Pharmacy, Al Azhar University, Assiut 71524, Egypt. \\ ${ }^{2}$ Department of Pharmacognosy, Faculty of Pharmacy, Assiut University, Assiut 71526, Egypt. \\ ${ }^{3}$ Department of Parasitology, Faculty of Medicine, Assiut University, Assiut 71526, Egypt. \\ ${ }^{4}$ Department of Pharmacognosy, Faculty of Pharmacy, Port Said University, Port Said 42526, Egypt. \\ ${ }^{5}$ Graduate School of Medicine, Dentistry and Pharmaceutical Sciences, Okayama University, Tsushima, Okayama 700 8530, Japan.
}

\section{ARTICLE INFO \\ Received on: 30/09/2019 \\ Accepted on: 25/11/2019 \\ Available online: 05/03/2020}

\section{Key words:}

Anacardiaceae, Mangifera indica, kernels, simultaneous

isolation, gallotannins,

Trichomonas vaginalis.

\begin{abstract}
Therapeutic alternatives are being searched for trichomoniasis as a result of the increased prevalence of metronidazoleresistant infections. Mangifera indica L. (Anacardiaceae) is an important tree with a long history in medicine. Traditionally, it has been used as an anti-diarrheal and anti-diabetic, and recently, its gallotannin-rich leaves and stem bark extracts have shown antiparasitic activities against various parasites. Aiming at exploring the anti-Trichomonas vaginalis activity of mango's gallotannins, an aqueous ethanol extract of fresh kernels of $M$. indica was phytochemically investigated. Based on a simple gel chromatographic procedure, ethyl gallate (2), a group of five isomeric tetragalloyl-glucoses (3-7), and a pentagalloylglucose (8) were simultaneously isolated from a single fraction by a preparative Reversed-phase-high performance liquid chromatography. The isolates were identified based on spectroscopic analyses and comparison with reported data. They showed structural-dependent inhibitory effects on the growth of $T$. vaginalis trophozoites in an in vitro investigation. Ethyl gallate and 1,2,4,6-tetra- $O$-galloyl- $\beta$-D-glucose (7) exhibited elevated anti- $T$. vaginalis activity $\left(\mathrm{IC}_{50}=1.3,2.4\right.$ $\mu \mathrm{g} / \mathrm{ml}$, respectively). This is the first report exploring the potential of gallotannins as trichomonacidal agents.
\end{abstract}

\section{INTRODUCTION}

Trichomonas vaginalis (T. vaginalis) is the most common sexually transmitted parasite. It affects the external genitalia of men and women leading to a genitourinary disease trichomoniasis. The infections are sometimes associated with preterm birth of pregnant women (Silver et al., 2014) and prostatic tumor of men (Sutcliffe et al., 2012). The development of resistance, allergy, and other side effects due to repeated treatment with imidazole derivatives urged exploring safe alternative anti-trichomoniasis (Cudmore et al., 2004). The gallotannins-rich leaves and stem bark of the tree

"Corresponding Author

Mohamed A. A. Orabi, Department of Pharmacognosy,

Faculty of Pharmacy, Al Azhar University, Assiut 71524, Egypt.

E-mail: mohamedorabi@azhar.edu.eg
Mangifera indica L. (Anacardiaceae)(Núñez Sellés et al., 2002) have shown antiparasitic activities against Entamoeba histolytica (Tona et al., 1998); Histomonas meleagridis, Tetratrichomonas gallinarum, and Blastocystis sp (Grabensteiner et al., 2008); Plasmodium falciparum (Awe et al., 1998; Ruiz et al., 2011; Zirihi et al., 2005); and Giardia lamblia (Amaral et al., 2006). The mango kernels largely produce gallotannins, gallic acid, and benzoic acid derivatives (Masibo and He, 2008). The kernels are a very rich source of gallotannins $(15.5 \mathrm{mg} / \mathrm{g}$ dry kernel; Berardini et al., 2004). It was traditionally employed to expel tapeworms and as an anti-diarrheal agent (Sairam et al., 2003). Extracts of the kernels have also demonstrated antimicrobial activities against a wide range of the Gram-positive organisms which were ascribed to its gallotannins content (Ahmed et al., 2007; Ka buki et al., 2000). In our previous report, gallotannins, benzophenones, and xanthone $C$-glucosides from the mango stem bark were shown 
together with their antiviral and cytotoxic activities (AbdelMageed et al., 2014). To explore the anti-T. vaginalis activity of the tannin constituents of the mango seed kernels, we conducted a phytochemical investigation focusing on the isolation of gallotannins. As a result, gallic acid (1), ethyl gallate (2), 2,3,4,6-tetra- $O$-galloyl- $\beta$-D-glucose (3), 1,2,3,4-tetra- $O$-galloyl$\beta$-D-glucose (4), and a combination of almost equal proportions of 1,2,3,6-tetra- $O$-galloyl- $\beta$-D-glucose (5) and 1,3,4,6-tetra- $O$ galloyl- $\beta$-D-glucose (6), 1,2,4,6-tetra- $O$-galloyl- $\beta$-D-glucose (7), and 1,2,3,4,6-penta- $O$-galloyl- $\beta$-D-glucose (8) were purified. This study reports an easy chromatographic procedure for the simultaneous isolation of ethyl gallate (2), and the six gallotannins (3-8, Fig. 1) from seed kernels of $M$. indica variety Tymor. The effect of these seven compounds on the viability of $T$. vaginalis trophozoites is also reported here for the first time. A growth inhibitory mechanism of the trophozoite is suggested in view of the known protein binding and iron-binding affinity of the tannins.

\section{MATERIALS AND METHODS}

\section{General experimental procedures}

The one-dimensional (1D) and two-dimensional (2D) nuclear magnetic resonance (NMR) spectra were recorded on a Varian INOVAAS 600 instrument (Agilent, Santa Clara, CA, USA; $0.151 \mathrm{GHz}$ for ${ }^{13} \mathrm{C}$ and $0.6 \mathrm{GHz}$ for $\left.{ }^{1} \mathrm{H}\right)$. The chemical shift values were shown in $\delta(\mathrm{ppm})$ relative to the solvent signals $\left[\left(\mathrm{CD}_{3}\right)_{2} \mathrm{CO}-d_{6}\right.$ $\left(\delta_{\mathrm{H}} 2.04 ; \delta_{\mathrm{C}} 29.8\right)$ on the tetramethylsilane (TMS) scale. Reversedphase-high performance liquid chromatography (RP-HPLC) was done on a YMC-Pack ODS-A A-303 (product of YMC, Japan) column (4.6 i.d. $\times 250 \mathrm{~mm})$ using acetonitrile - water $(2: 8, \mathrm{v} / \mathrm{v})$ with $0.1 \%$ acetic acid. The flow rate was set at $1 \mathrm{ml} / \mathrm{min}$ and the oven temperature at $40^{\circ} \mathrm{C}$. The eluates were monitored by a Ultraviolet (UV) detector at $\lambda_{\text {max }}=280 \mathrm{~nm}$. Preparative RP-HPLC was carried out on a YMC-Pack ODS-A, A-324 column $(10$ i.d. $\times 300 \mathrm{~mm})$ using the mobile phase acetonitrile - water $(2: 8, \mathrm{v} / \mathrm{v})$ with $0.1 \%$ acetic acid. The flow rate of $2 \mathrm{ml} / \mathrm{min}$ at column oven temperature $40^{\circ} \mathrm{C}$, and UV detection $\left(\lambda_{\max }=280 \mathrm{~nm}\right)$ were applied. The gels, Dia-ion HP-20 and MCI-gel CHP-20P (products of Mitsubishi Chemical, Japan), were used for the chromatographic experiments.

\section{Plant material}

Fresh seed kernels of $M$. indica variety Tymor were collected from mature ripe fruits which were purchased from a private farm in Assiut. The plant species was identified by Prof. Dr. Ayman Kotb, Horticulture Department, Faculty of Agriculture, Assiut University. An authentic sample (No. 2012MT) was kept in the Department of Pharmacognosy, Faculty of Pharmacy, Assiut University, Assiut, Egypt.

\section{Extraction and isolation procedures}

Mangifera indica fresh seed kernels $(\sim 2.5 \mathrm{~kg})$ were extracted by maceration in EtOH/water [7:3, v/v, $(3 \mathrm{~L} \times 4)]$ at ambient temperature. The obtained extract was concentrated under vacuum at $\sim 40^{\circ} \mathrm{C}$. The obtained concentrate $(\sim 400 \mathrm{ml})$ was applied to a Diaion HP-20 column $(5.5$ i.d. $\times 63 \mathrm{~cm})$, which was eluted with distilled water $(6 \mathrm{~L})$, methanol/water $(2.5: 7.5, \mathrm{v} / \mathrm{v}, 5 \mathrm{~L})$, methanol/ water $(5: 5, \mathrm{v} / \mathrm{v}, 5 \mathrm{~L})$, methanol/water $(7.5: 2.5, \mathrm{v} / \mathrm{v}, 5 \mathrm{~L})$, and methanol ( $5 \mathrm{~L})$ successively. The respective eluates were dried under vacuum and yielded the respective water $(54 \mathrm{~g})$, methanol/water $(2.5: 7.5$, $\mathrm{v} / \mathrm{v})(98.5 \mathrm{~g})$, methanol/water $(5: 5, \mathrm{v} / \mathrm{v})(55 \mathrm{~g})$, methanol/water $(7.5: 2.5, \mathrm{v} / \mathrm{v})(4.7 \mathrm{~g})$, and methanol $(4.4 \mathrm{~g})$ fractions. A portion (3 g) of the methanol/water $(2.5: 7.5, \mathrm{v} / \mathrm{v})$ fraction was subjected to chromatographic purification on MCI-gel CHP-20P (1.1 i.d. $\times 37$ $\mathrm{cm})$ with water, water/methanol $(9: 1 \rightarrow 8.5: 1.5 \rightarrow 8: 2 \rightarrow 7.5: 2.5$ $\rightarrow 7: 3 \rightarrow 6.5: 3.5 \rightarrow 6: 4 \rightarrow 3: 7$ and $0: 10, \mathrm{v} / \mathrm{v})$. All the 700 drops of<smiles>CCOC(=O)c1cc(O)c(O)c(O)c1</smiles><smiles>CCC(CO)(COC(=O)c1cc(O)c(O)c(O)c1)COC(=O)c1cc(O)c(O)c(O)c1</smiles><smiles>O=C(Oc1cc(O)c(O)c(O)c1)c1cc(O)c(O)c(O)c1</smiles>

2
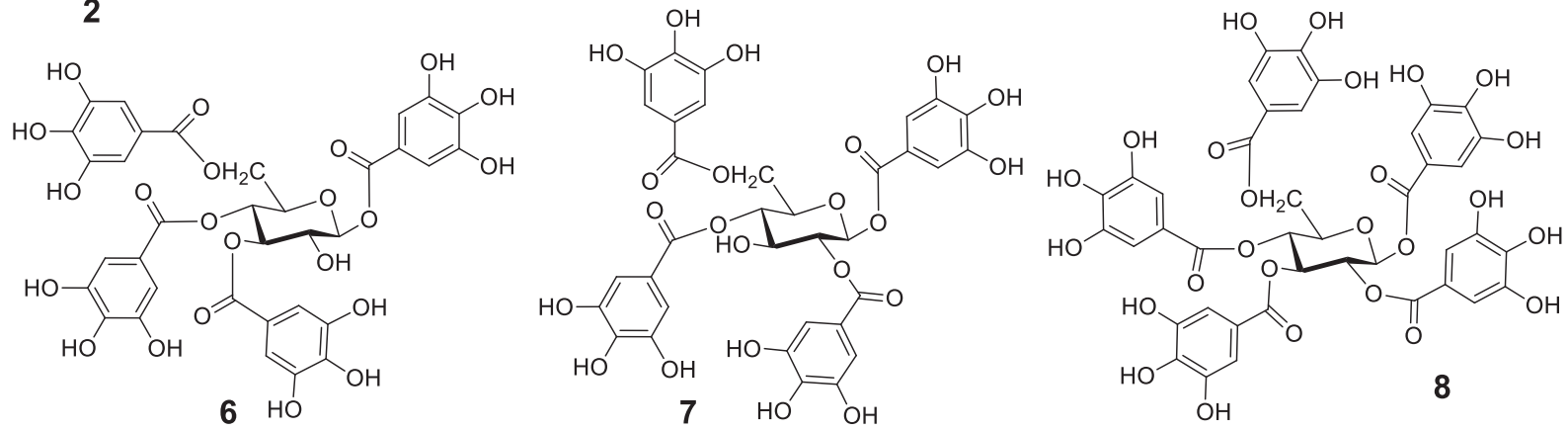

Figure 1. Structures of gallic acid (1) ethyl gallate (2), and the gallotannins 3-8 
the column eluates were gathered separately in a test tube using a fraction collector. The fractions were visualized by monitoring the RP-HPLC. The water eluate furnished crude gallic acid [1 (519 $\mathrm{mg})]$. The water/methanol $(8.5: 1.5, \mathrm{v} / \mathrm{v})$ eluate provided pure ethyl gallate $[2,(383 \mathrm{mg})]$. The water/methanol $(8: 2,133 \mathrm{mg}),(7.5: 2.5$, $222 \mathrm{mg})$, and $(7: 3, \mathrm{v} / \mathrm{v}, 221.4 \mathrm{mg})$ eluates demonstrated identical RP-HPLC profiles (Fig. 2), indicating the presence of the same compounds in these elutes. A preparative HPLC purification of part (300 mg) of the water/methanol $(7.5: 2.5, \mathrm{v} / \mathrm{v})$ eluted fraction led to purification of 2,3,4,6-tetra- $O$-galloyl- $\beta$-D-glucose [3, $(4.2 \mathrm{mg})]$, 1,2,3,4-tetra- $O$-galloyl- $\beta$-D-glucose $[4,(3 \mathrm{mg})]$, mixture $(13.4 \mathrm{mg})$ of almost equal proportions of 1,2,3,6-tetra- $O$-galloyl- $\beta$-D-glucose (5) and 1,3,4,6-tetra- $O$-galloyl- $\beta$-D-glucose (6), 1,2,4,6-tetra- $O$ -

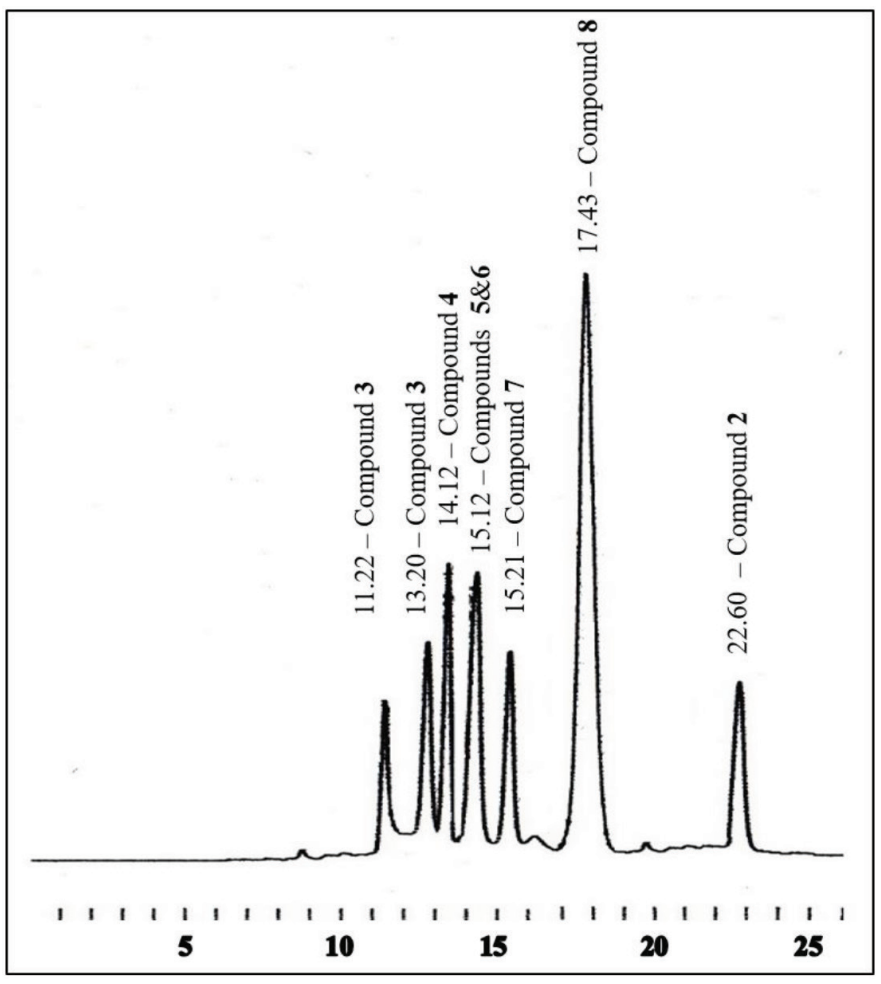

Figure 2. RP-HPLC chromatogram (at $\lambda_{\max }=280 \mathrm{~nm}$ ) of the main compounds in the water/methanol $(8: 2-6.5: 3.5$, v/v) eluates from an MCI-gel CHP20P column, from the water/methanol $(8: 2, \mathrm{v} / \mathrm{v})$ eluate of the dia-ion HP-20 chromatographic fractionation for the aq. EtOH extract of mango seed kernels. galloyl- $\beta$-D-glucose [7, (5 mg)], 1,2,3,4,6-penta- $O$-galloyl- $\beta$-Dglucose $[8,(29 \mathrm{mg})]$, and another pure sample of the ethyl gallate [2, (34.8 mg)]. In addition, the water/methanol (6:4, v/v) eluted fraction also afforded 1,2,3,4,6-penta- $O$-galloyl- $\beta$-D-glucose $[8,(188.5 \mathrm{mg})]$.

\section{Compounds physicochemical and spectroscopic data}

Gallic acid (1): White, non-crystalline powder; RPHPLC analysis and co-chromatography with authentic sample $\left(\mathrm{t}_{R}=3.80 \mathrm{~min}\right) ;{ }^{1} \mathrm{H} \mathrm{NMR}\left[0.6 \mathrm{GHz} ;\left(\mathrm{CD}_{3}\right)_{2} \mathrm{CO}-d_{6} / \mathrm{D}_{2} \mathrm{O}, 9: 1\right] \delta_{\mathrm{H}}$ : $7.08(2 \mathrm{H}, \mathrm{s}, \mathrm{H}-2,6)$; Electrospray ionization mass spectrometry (ESIMS) $m / z 171[\mathrm{M}+\mathrm{H}]^{+}\left(\mathrm{C}_{7} \mathrm{H}_{7} \mathrm{O}_{5}\right)$.

Ethyl gallate (2): Off-white, non-crystalline powder; ${ }^{1} \mathrm{H}$ NMR [0.6 GHz; $\left.\left(\mathrm{CD}_{3}\right)_{2} \mathrm{CO}-d_{6} / \mathrm{D}_{2} \mathrm{O}, 9: 1\right] \delta_{\mathrm{H}}: 7.07(2 \mathrm{H}, \mathrm{s}$, galloyl $\mathrm{H}-2,6), 4.22\left(2 \mathrm{H}, \mathrm{q}, J=7.2 \mathrm{~Hz}, \mathrm{CH}_{2}\right), 1.27(3 \mathrm{H}, \mathrm{t}, J=7.2 \mathrm{~Hz}$, $\left.\mathrm{CH}_{3}\right) ;{ }^{13} \mathrm{C}$ NMR $\left[0.151 \mathrm{GHz} ;\left(\mathrm{CD}_{3}\right)_{2} \mathrm{CO}-d_{6} / \mathrm{D}_{2} \mathrm{O}, 9: 1\right]: \delta_{\mathrm{C}} 167(\mathrm{C}-$ 7), 145.9 (2C, C-3,5), 138.7 (C-4), 121.6 (C-1), 109.6 (2C, C-2,6), $61(\mathrm{C}-8)$ and 14.5 (C-9); ESIMS $m / z 199[\mathrm{M}+\mathrm{H}]^{+}\left(\mathrm{C}_{9} \mathrm{H}_{11} \mathrm{O}_{5}\right)$.

2,3,4,6-Tetra-O-galloyl- $\beta$-D-glucose (3): Off-white, noncrystalline powder; ${ }^{1} \mathrm{H}$ NMR $\left[0.6 \mathrm{GHz} ;\left(\mathrm{CD}_{3}\right)_{2} \mathrm{CO}-d_{6} / \mathrm{D}_{2} \mathrm{O}, 9: 1\right] \delta_{\mathrm{H}}$ : $7.13,7.02,7.00,6.92$ [each s, $2 \mathrm{H}$, galloyl $\mathrm{H}-2,6 \times 4$ ], galloyls of the $\beta$-anomer of the D-glucose, 7.15, 7.03, 7.028, 6.98 [each $\mathrm{s}$, $2 \mathrm{H}$, galloyl H-2,6 $\times 4$ ], galloyls of the $\alpha$-anomer of the D-glucose, glucose protons (Table 1); ESIMS $m / z 789[\mathrm{M}+\mathrm{H}]^{+}\left(\mathrm{C}_{34} \mathrm{H}_{29} \mathrm{O}_{22}\right)$.

1,2,3,4-Tetra-O-galloyl- $\beta$-D-glucose (4): Off-white, non-crystalline powder; ${ }^{1} \mathrm{H}$ NMR $\left[0.6 \mathrm{GHz} ;\left(\mathrm{CD}_{3}\right)_{2} \mathrm{CO}-d_{6} / \mathrm{D}_{2} \mathrm{O}\right.$, 9:1] $\delta_{\mathrm{H}}: 7.07,7.025,6.98,6.95$ (each s, 2H, galloyl H-2,6 $\times 4$ ), glucose protons (Table 1); ESIMS $m / z 789[\mathrm{M}+\mathrm{H}]^{+}\left(\mathrm{C}_{34} \mathrm{H}_{29} \mathrm{O}_{22}\right)$.

1,2,3,6-Tetra-O-galloyl- $\beta$-D-glucose (5): Off-white, non-crystalline powder; ${ }^{1} \mathrm{H}$ NMR $\left[0.6 \mathrm{GHz} ;\left(\mathrm{CD}_{3}\right)_{2} \mathrm{CO}-d_{6} / \mathrm{D}_{2} \mathrm{O}\right.$, 9:1] $\delta_{\mathrm{H}}: 7.13,7.06,7.04,6.98$ (each $\mathrm{s}, 2 \mathrm{H}$, galloyl $\mathrm{H}-2,6 \times 4$ ], glucose protons (Table 1); ESIMS m/z $789[\mathrm{M}+\mathrm{H}]^{+}\left(\mathrm{C}_{34} \mathrm{H}_{29} \mathrm{O}_{22}\right)$.

1,3,4,6-Tetra-O-galloyl- $\beta$-D-glucose (6): Off-white, non-crystalline powder; ${ }^{1} \mathrm{H}$ NMR $\left[0.6 \mathrm{GHz} ;\left(\mathrm{CD}_{3}\right)_{2} \mathrm{CO}-d_{6} / \mathrm{D}_{2} \mathrm{O}\right.$, 9:1] $\delta_{\mathrm{H}}: 7.16,7.10,7.05,7.02$ (each $\mathrm{s}, 2 \mathrm{H}$, galloyl $\mathrm{H}-2,6 \times 4$ ], glucose protons (Table 1); ESIMS $m / z 789[\mathrm{M}+\mathrm{H}]^{+}\left(\mathrm{C}_{34} \mathrm{H}_{29} \mathrm{O}_{22}\right)$.

1,2,4,6-Tetra-O-galloyl- $\beta$-D-glucose (7): Off-white, non-crystalline powder; ${ }^{1} \mathrm{H}$ NMR $\left[0.6 \mathrm{GHz} ;\left(\mathrm{CD}_{3}\right)_{2} \mathrm{CO}-d_{6} / \mathrm{D}_{2} \mathrm{O}\right.$, 9:1] $\delta_{\mathrm{H}}: 7.14,7.11,7.08,7.05$ (each $\mathrm{s}, 2 \mathrm{H}$, galloyl $\mathrm{H}-2,6 \times 4$ ), glucose protons (Table 1); ESIMS $m / z 789[\mathrm{M}+\mathrm{H}]^{+}\left(\mathrm{C}_{34} \mathrm{H}_{29} \mathrm{O}_{22}\right)$.

1,2,3,4,6-Penta-O-galloyl- $\beta$-D-glucose (8): Off-white, non-crystalline powder; ${ }^{1} \mathrm{H}$ NMR $\left[0.6 \mathrm{GHz} ;\left(\mathrm{CD}_{3}\right)_{2} \mathrm{CO}-d_{6} / \mathrm{D}_{2} \mathrm{O}\right.$,

Table 1. ${ }^{~} \mathrm{H}$ NMR data $(\delta$ in ppm, $J$ in $\mathrm{Hz})$ of glucose moiety of the galloylglucoses 3-8 $\left(0.6 \mathrm{GHz},\left(\mathrm{CD}_{3}\right)_{2} \mathrm{CO}-d_{6} / \mathrm{D}_{2} \mathrm{O}, 9: 1,27^{\circ} \mathrm{C}\right)$.

\begin{tabular}{|c|c|c|c|c|c|c|c|}
\hline \multirow{2}{*}{ glc. H } & \multicolumn{2}{|c|}{3} & \multirow{2}{*}{4} & \multirow{2}{*}{5} & \multirow{2}{*}{6} & \multirow{2}{*}{7} & \multirow{2}{*}{8} \\
\hline & $3 \alpha$ & $3 \beta$ & & & & & \\
\hline 1 & $5.55(\mathrm{~d}, 3.6)$ & $5.16(\mathrm{~d}, 7.8)$ & $6.19(\mathrm{~d}, 8.4)$ & $6.10(\mathrm{~d}, 8.4)$ & $5.96(\mathrm{~d}, 8.4)$ & $6.03(\mathrm{~d}, 8.4)$ & $6.27(\mathrm{~d}, 8.4)$ \\
\hline 2 & $5.11(\mathrm{dd}, 3.6,10.2)$ & $5.26(\mathrm{dd}, 7.8,10.2)$ & $5.55(\mathrm{dd}, 8.4,9.6)$ & $5.45(\mathrm{dd}, 8.4,9.6)$ & $4.023(\mathrm{dd}, 8.4,9.6)$ & $5.37(\mathrm{dd}, 8.4,9.6)$ & $5.62(\mathrm{~d}, 8.4,9.6)$ \\
\hline 3 & $6.04(\mathrm{t}, 10.2)$ & $5.75, \mathrm{t}$ & $5.92, \mathrm{t}$ & $5.64, \mathrm{t}$ & $5.65, \mathrm{t}$ & $4.35, \mathrm{t}$ & $6.00, \mathrm{t}$ \\
\hline 4 & $5.55(\mathrm{t}, 10.2)$ & $5.47(\mathrm{t}, 10.2)$ & $5.46(\mathrm{t}, 9.6)$ & $4.04(\mathrm{t}, 9.6)$ & $4.04(t, 9.6)$ & $5.38(\mathrm{t}, 9.6)$ & $5.65(\mathrm{t}, 9.6)$ \\
\hline 5 & $\begin{array}{c}4.58 \\
(\mathrm{ddd}, 1.8,6.6,10.2)\end{array}$ & $\begin{array}{c}4.24 \\
(\mathrm{ddd}, 1.8,6.6,10.2)\end{array}$ & $\begin{array}{c}4.16 \\
(\mathrm{ddd}, 1.8,4.8,10.2)\end{array}$ & $\begin{array}{c}4.14 \\
(\mathrm{ddd}, 2.4,5.4,9.6)\end{array}$ & $\begin{array}{c}4.35 \\
(\mathrm{ddd}, 2.4,5.4,9.6)\end{array}$ & $\begin{array}{c}4.29 \\
(\mathrm{ddd}, 1.8,4.8,9.6)\end{array}$ & $\begin{array}{c}4.54 \\
(\mathrm{ddd}, 1.8,4.8,9.6)\end{array}$ \\
\hline 6 & $\begin{array}{c}4.24 \\
(\mathrm{dd}, 4.8,12)\end{array}$ & $\begin{array}{c}4.24 \\
(\mathrm{dd}, 4.8,12)\end{array}$ & $\begin{array}{c}3.73 \\
(\mathrm{dd}, 1.8,12)\end{array}$ & $\begin{array}{c}4.63 \\
(\mathrm{dd}, 1.8,12)\end{array}$ & $\begin{array}{c}4.51 \\
(\mathrm{dd}, 2.4,12)\end{array}$ & $\begin{array}{c}4.52 \\
(\mathrm{dd}, 1.8,12.6)\end{array}$ & $\begin{array}{c}4.57 \\
(\mathrm{dd}, 1.8,12.6)\end{array}$ \\
\hline & $\begin{array}{c}4.50 \\
(\mathrm{dd}, 1.8,13.2)\end{array}$ & $\begin{array}{c}4.50 \\
(\mathrm{dd}, 1.8,13.2)\end{array}$ & $\begin{array}{c}3.65 \\
(\mathrm{dd}, 4.8,13.2)\end{array}$ & $\begin{array}{c}4.46 \\
(\mathrm{dd}, 4.8,12)\end{array}$ & $\begin{array}{c}4.21 \\
(\mathrm{dd}, 4.8,12)\end{array}$ & $\begin{array}{c}4.19 \\
(\mathrm{dd}, 4.8,12.6)\end{array}$ & $\begin{array}{c}4.3 \\
(\mathrm{dd}, 4.8,12.6)\end{array}$ \\
\hline
\end{tabular}


9:1] $\delta_{\mathrm{H}}: 7.13,7.07,7.04,6.99,6.97$ (each s, $2 \mathrm{H}$, galloyl H-2,6 $\times 5$ ), glucose protons (Table 1); ESIMS $m / z 941[\mathrm{M}+\mathrm{H}]^{+}\left(\mathrm{C}_{41} \mathrm{H}_{33} \mathrm{O}_{26}\right)$.

\section{Anti-T. vaginalis activity of the isolated compounds}

Culture of $\mathrm{T}$. vaginalis

Fresh $T$. vaginalis was isolated from a female patient visiting the Patient Treatment Center, Gynecology and Obstetrics Hospital, Faculty of Medicine, Assiut University. After explaining the aim of the study, informative consent was signed by the patient. This study was endorsed by the Research Ethics Committee, Faculty of Medicine, Assiut University, Egypt. The live trophozoites were grown in trypticase-yeast extract-maltose (TYM) medium (Innocente et al., 2014) in $15-\mathrm{ml}$ screw-stoppered glass tubes at $37^{\circ} \mathrm{C}$. The medium was complemented with 1-ml heat-inactivated fetal calf serum, crystalline penicillin $(1,000,000 \mathrm{IU} / \mathrm{ml})$, and streptomycin sulfate $(100,000 \mu \mathrm{g} / \mathrm{ml})$, and the $\mathrm{pH}$ was adjusted at 6.0 . The isolate was regularly transferred to fresh TYM medium every 48 hours, and maintained in the Parasitology Department, Faculty of Medicine, Assiut University. The growth of T. vaginalis was monitored until it reached the logarithmic growth phase. The trophozoites exhibiting normal viability and morphology were harvested, isolated from the medium by centrifugation, and regrown in fresh TYM medium for the investigations; $10^{5} / \mathrm{ml}$ cells were used for the evaluation of the anti-trichomonal effect of the isolated compounds. The organism count number was monitored using hemocytometer slides.

\section{The trichomonacidal assay}

The anti- $T$. vaginalis activity of the pure compounds (2-8) was determined in vitro based on the reported method (Ibrahim, 2013). The test compounds were diluted by DMSO as solubilizing vehicle at a concentration not more than $0.01 \%$ in the experiment medium. A series of two-fold dilutions for all compounds tested were obtained and used at final concentrations of $50,25,12.5,6.25,3.12,1.56 \mu \mathrm{g} / \mathrm{ml}$. A $50 \mu \mathrm{l}$ of $1 \times 10^{5}$ trophozoite/ml was inoculated in $150 \mu \mathrm{l}$ of the test compound in a sterile 96 -well culture plate at $37^{\circ} \mathrm{C}$ (Innocente et al., 2014). Three controls were considered: negative control with parasites only; vehicle control (DMSO); and the positive control [metronidazole (MTZ) (Sanofi-Aventis, Egypt). MTZ was dissolved in distilled $\mathrm{H}_{2} \mathrm{O}$, diluted by the incubation medium giving four concentrations, $3.12,1.56,0.75$, and 0.0037 $\mu \mathrm{g} / \mathrm{ml}$, and used as the reference standard. The 96-well plate was incubated for 72 hours at $37^{\circ} \mathrm{C}, 5 \% \mathrm{CO}_{2}$. The number of living organisms was determined by counting the parasites by a hemocytometer using the trypan blue dye $(0.2 \%)$ exclusion method. Control cultures were treated by the same procedure as that of the test cultures. All assays were carried out in triplicate and repeated three times. For evaluation of the activity of the compound at different contact times, samples from the cultures were taken after 24-, 48-, and 72-hours incubations. The mortality percentage of the parasites was determined from the equation $\{100 \times[100-\mathrm{a} / \mathrm{b}]\}$ where "a" is the living organisms count in test wells and "b" is the living organisms count in the control wells (Ali, 2007).

\section{Statistical analysis}

The $\mathrm{IC}_{50}$ values were computed from a non-linear regression curve using the GraphPad Prism 5.0 software.

\section{RESULTS AND DISCUSSION}

\section{Simultaneous isolation of gallotannins}

The development of analytical technique Liquid chromatography mass spectrometry/mass spectrometry (LCMS/ MS) made profiling and identification of multi-components of plant extracts more rapid. Identification of a series of gallotannins in extracts of morphological parts of mango (peel, pulp, and kernel) by such technique has recently been reported (Berardini et al., 2004). However, estimation of the activity of the individual gallotannins, as well as its pharmacokinetic and pharmacodynamic parameters, are largely dependent on the tannin structure (Berardini et al., 2004, Gan et al., 2018), which necessitate obtaining the tannin in pure form. We herein succeeded to simultaneously purify a group of five isomeric tetragalloyl glucoses (3-7), a pentagalloyl glucose (8), and a tannin related compound, ethyl gallate (2), based on a preparative RP-HPLC purification of a crude tannin mixture obtained from gel chromatography. Briefly, a concentrated aqueous EtOH extract of fresh mango kernels was fractionated on a Diaion HP-20 column with methanol/water gradients $(0: 10 \rightarrow 2.5: 7.5$ $\rightarrow 5: 5 \rightarrow 10: 0, \mathrm{v} / \mathrm{v})$. The methanol/water $(2.5: 7.5, \mathrm{v} / \mathrm{v})$ eluted fraction was further fractionated on an MCI-gel CHP-20P with water, water/methanol gradients $(9: 1 \rightarrow 8.5: 1.5 \rightarrow 8: 2 \rightarrow 7.5: 2.5$ $\rightarrow 7: 3 \rightarrow 6.5: 3.5 \rightarrow 6: 4 \rightarrow 3: 7$ ), and methanol. Then, simultaneous isolation of the compounds $\mathbf{2 - 8}$ (Fig. 1) was attained by RP-HPLC purification of the water/methanol $(7.5: 2.5, \mathrm{v} / \mathrm{v})$ eluate on A-324 (10 i.d. $\times 300 \mathrm{~mm}$ ) ODS-A column (YMC-Pack) using $\mathrm{CH}_{3} \mathrm{CN}-$ water $(2: 8, \mathrm{v} / \mathrm{v})$ acidulated with $1 \mathrm{ml} / \mathrm{L}$ acetic acid. A $2 \mathrm{ml} / \mathrm{min}$ flow rate at column oven $40^{\circ} \mathrm{C}$ was used, and the eluates were monitored by a UV detector set at $\lambda_{\max } 280 \mathrm{~nm}$.

The easy and fast isolation procedures described here for gallotannins could be useful for the rapid purification of such compounds from other gallotannins-rich plants including other morphological parts of $M$. indica.

\section{Identification of the isolated compounds}

Analysis of the data obtained from ESIMS and NMR spectroscopic experiments, ${ }^{1} \mathrm{H},{ }^{13} \mathrm{C} \quad{ }^{1} \mathrm{H}-{ }^{1} \mathrm{H}$ correlation spectroscopy (COSY), heteronuclear single quantum correlation (HSQC), and heteronuclear multiple bond correlation (HMBC), and comparison of the found data with literature ones, allowed identification of compounds $\mathbf{1}$ and $\mathbf{2}$ as gallic acid (Lee et al., 2005) and ethyl gallate (Cui et al., 2002), and galloylglucoses (3-8) as 2,3,4,6-tetra- $O$-galloyl- $\beta$-D-glucose (3) (Haddock et al., 1982), 1,2,3,4-tetra- $O$-galloyl- $\beta$-D-glucose (4) (Berardini et al., 2004), mixture of almost equal proportions of 1,2,3,6-tetra$O$-galloyl- $\beta$-D-glucose (5) (Hagenah and Gross, 1993) and 1,3,4,6-tetra-O-galloyl- $\beta$-D-glucose (6) (Haddock et al., 1982), 1,2,4,6-tetra- $O$-galloyl- $\beta$-D-glucose (7) (Haddock et al. 1982), and 1,2,3,4,6-penta-O-galloyl- $\beta$-D-glucose (8) (Haddock et al., 1982). Worthy, gallic acid (1), ethyl gallate (2), and the pentagalloylglucose (8) are the most abundant isolates.

\section{Anti-T. vaginalis activities of the isolated compounds}

Secondary metabolites from natural sources have played a unique role in the discovery of anti-infectious compounds. Studies on the inhibitory effects of plant extracts on the growth of $T$. vaginalis trophozoites evidenced that extracts from the volatile oils producing plants Mentha piperita, Salvia officinalis, 
and Tanacetum parthenium demonstrate anti-T. vaginalis activity identical to MTZ (Ezz Eldin and Badawy, 2015; Sharafi et al., 2013). A commercial garlic-based product $\left(\right.$ Tomex $^{\circledR}$ ) has been also shown to significantly reduce the multiplication and motility of the T. vaginalis trophozoites (Ali, 2007). In another study, the hydrolyzable tannins containing ethyl acetate fraction of a Eucalyptus extract exhibited MTZ-like activity on the growth of the Trichomonas trophozoites (Hassani et al., 2013). Meanwhile, limited research on the effects of pure compounds from natural sources, such as berberine alkaloid (de Brum Vieira et al., 2015; Sharafi et al., 2013) and piperazinyl derivatives of betulinic acid (Innocente et al., 2014), have been reported.

Herein, the effect of a group of gallotannins and ethyl gallate from kernels of $M$. indica on the viability of $T$. vaginalis
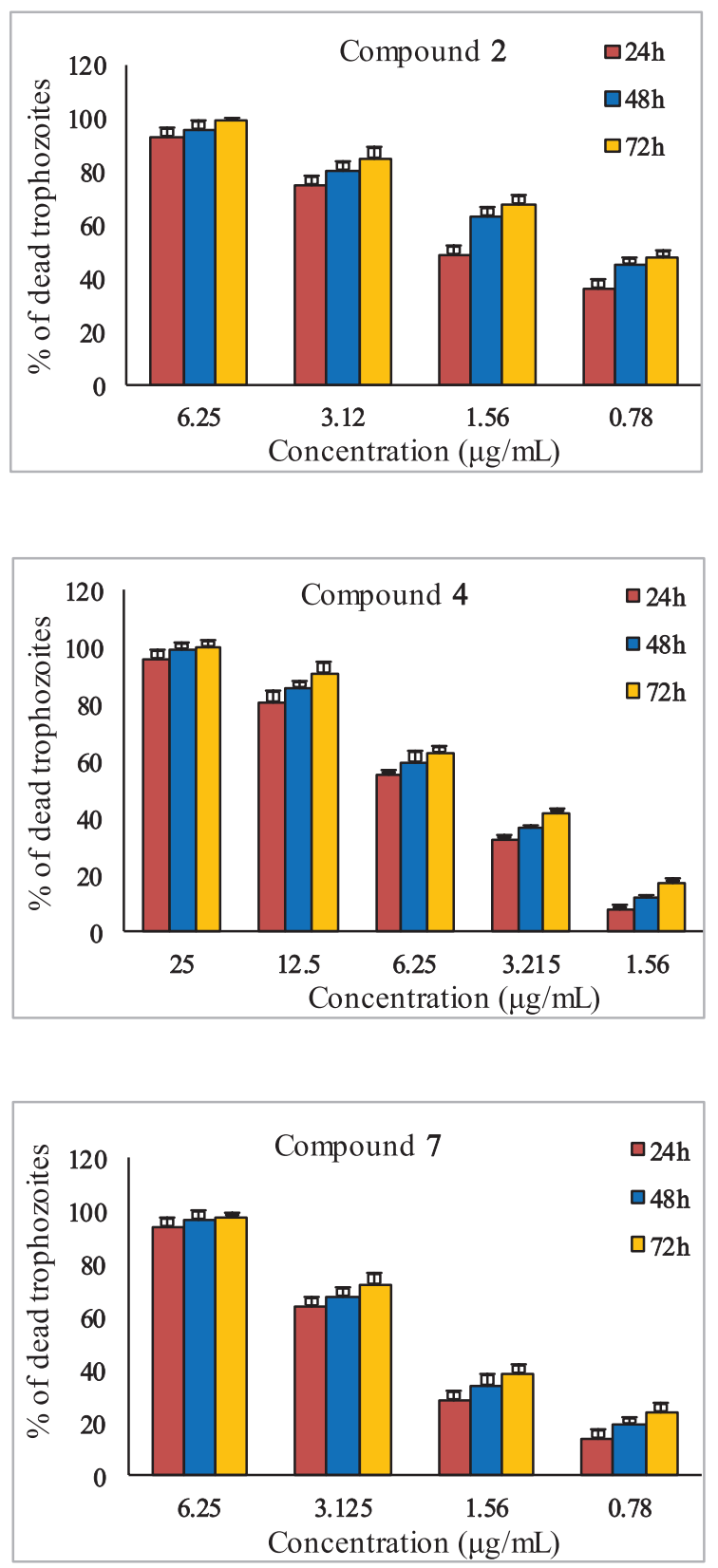

clinical isolates was estimated (see experimental section). Although the common chemical nature of the investigated compounds, galloyl esters of a glucose core (Fig. 1), their antiprotozoal activities were varied based on the molecular structure (Fig. 3). All the examined compounds (2-8) exhibited a remarkable dosedependent and time-dependent decrease in the percentage of living trophozoites (Fig. 3). After 24 hours of incubation, ethyl gallate, a tannin-related compound, showed the highest inhibitory effect on the $T$. vaginalis trophozoites viability $\left(\mathrm{IC}_{50} 1.3 \mu \mathrm{g} / \mathrm{ml}\right.$, Fig. 4). The gallotannin with an unacylated O-3 position of the glucose core, 1,2,4,6-tetra- $O$-galloyl- $\beta$-D-glucose (7), exerted a potent effect $\left(\mathrm{IC}_{50} 2.4 \mu \mathrm{g} / \mathrm{ml}\right.$ ), while the inhibitory effect of $\sim 1: 1$ mixture of $\mathbf{5}$ and $\mathbf{6}$ on the $T$. vaginalis trophozoites was relatively low $\left(\mathrm{IC}_{50} 36.1 \mu \mathrm{g} / \mathrm{ml}\right)$. The other gallotannins $(\mathbf{3}, \mathbf{4}$ and $\mathbf{8})$ exhibited
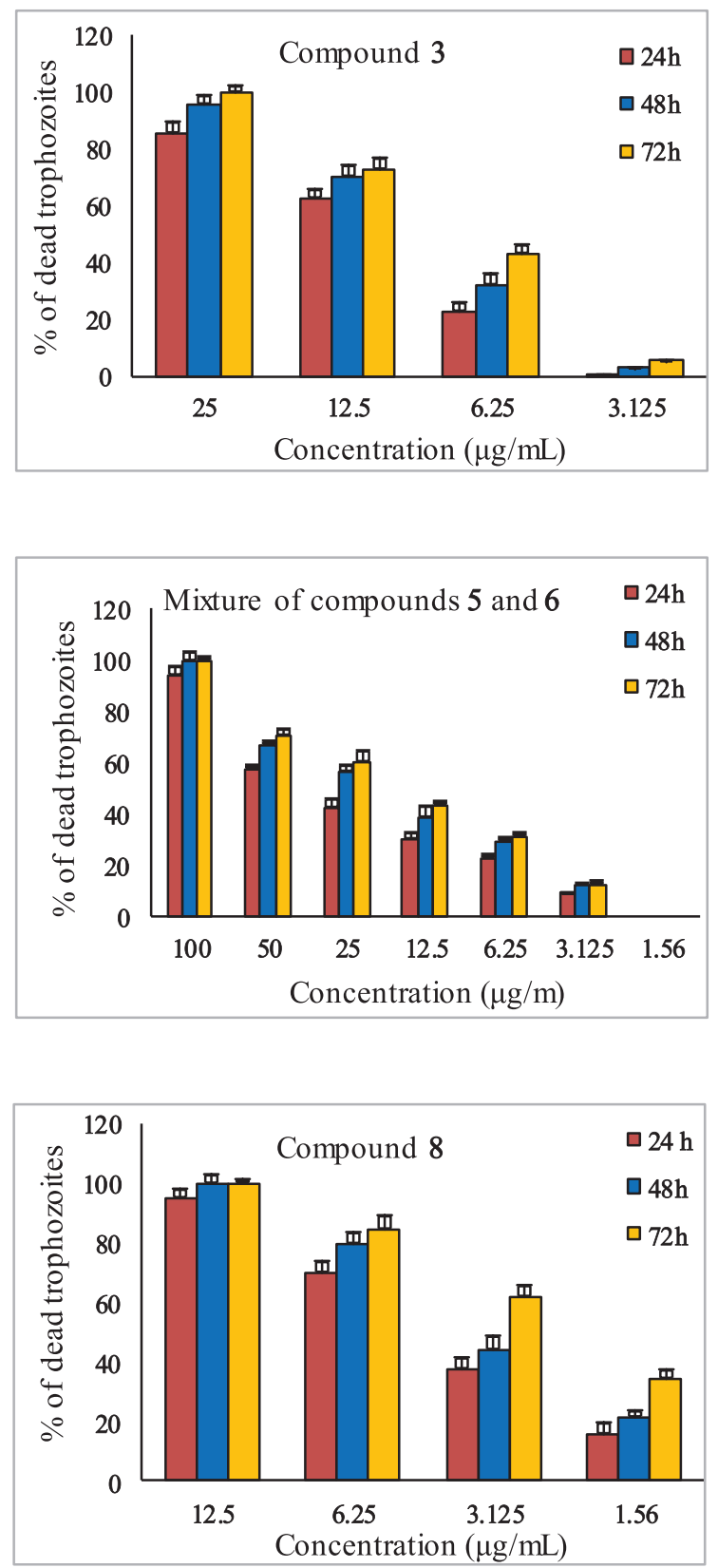

Figure 3. In vitro inhibitory effects of the compounds $\mathbf{2 - 8}$ on viability of $T$. vaginalis trophozoites. The bars represent standard division (SD) of the means. 


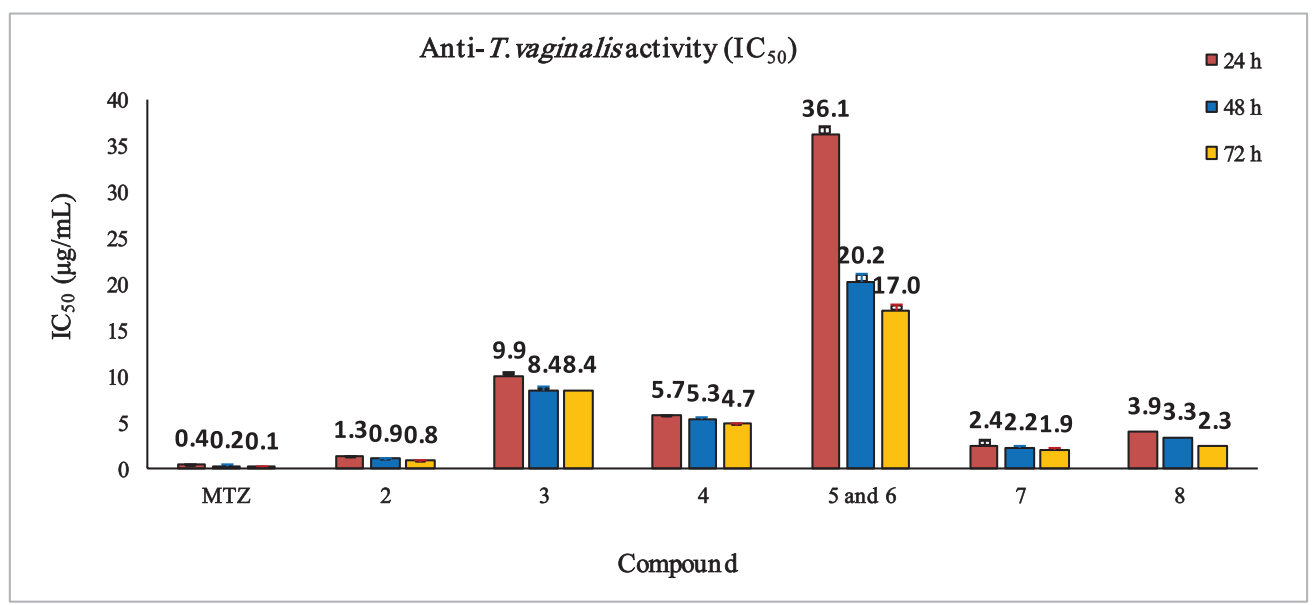

Figure 4. $\mathrm{IC}_{50}$ of the compounds $\mathbf{2}-\mathbf{8}$ on $T$. vaginalis clinical isolate compared to a standard control (MTZ). The bars represent $\mathrm{SD}$ of the means.

noticeable anti- $T$. vaginalis activities with comparable potencies $\left(\mathrm{IC}_{50} 3.9-9.9 \mu \mathrm{g} / \mathrm{ml}\right)$. Due to the presence of some differences in the activity of the examined gallotannins, a structural activity relationship can't be generated because of the limited number of the investigated compounds.

The broad-spectrum antiprotozoal activities of the mango leaf and stem bark extracts (Núñez Sellés et al., 2002) against Entamoeba histolytica (Tona et al., 1998), Histomonas meleagridis, Tetratrichomonas gallinarum and Blastocystis sp (Grabensteiner et al., 2008), Plasmodium falciparum (Awe et al., 1998; Ruiz et al., 2011; Zirihi et al., 2005), and Giardia lamblia (Amaral et al., 2006) agree with our herein obtained results. In addition, the reported leishmanicidal activity of several tannins against amastigotes of Leishmania donovani (Kolodziej et al., 2001) also supports our results. Likewise, the antibacterial activity of gallotannins and/ or extracts of mango kernels on different bacterial species have been also shown in several reports (El-Gied et al., 2012; Engels et al., 2010; Ka buki et al., 2000; Rajan et al., 2011; Rakholiya et al., 2015; Shabani and Sayadi, 2014; Subbiya et al., 2013). The antimicrobial properties of the kernel gallotannins were ascribed to its ability to intermingle with proteins, hinder the enzyme activity (Rajan et al., 2011), and/or its ability to make a complex with metal ions such as iron (Engels et al., 2009). Altogether, the anti- $T$. vaginalis activity of the isolated gallotannins may be attributed to either or all of the aforementioned mechanisms. T. vaginalis uses the iron-containing proteins lactoferrin and hemoglobin (Sehgal et al., 2012 delivered by the menstruation blood (Figueroa-Angulo et al., 2012). A study on the effect of iron deficiency in the host on $T$. vaginalis demonstrated changes in the parasite propagation, cytotoxicity, and immune evasion (Alvarez-Sánchez et al., 2007). Therefore, iron deficiency by complexation with gallotannins may be the cause of the trophozoite cellular damage and the parasite survival inhabitation at the experimental conditions.

\section{CONCLUSION}

We are reporting here on the accumulation of gallotannins (galloylglucoses), gallic acid, and gallate derivatives in mango kernels. The procedure as described here is an easy and fast isolation for gallotannins that could be useful for the preparation of these compounds either as a crude fraction or single pure sample from the kernels and from gallotannins-rich plant extracts including other morphological parts of $M$. indica. The present study demonstrated, to the first time, that the mango kernels along with its isolated gallotannins and ethyl gallate could be used for further studies on the development of novel preventive or therapeutic agents for the treatment of trichomoniasis. However, it is still required to achieve animal lab-work and more mechanistic studies to approve our in vitro finding.

\section{CONFLICTS OF INTEREST}

The authors declare that they have no conflict of interest.

\section{REFERENCES}

Abdel-Mageed WM, Bayoumi SA, Chen C, Vavricka CJ, Li L, Malik A, Dai H, Song F, Wang L, Zhang J, Gao GF, Lv Y, Liu L, Liu X, Sayed HM, Zhang L. Benzophenone $C$-glucosides and gallotannins from Mango tree stem bark with broad-spectrum anti-viral activity. Bioorg Med Chem, 2014; 22 (7):2236-43.

Ahmed A, Saeid D, Eman A, Reham E. Egyptian mango byproduct 1 . Compositional quality of mango seed kernel. Food Chem, 2007; 103(4):1141-52.

Ali NM. In vitro activity of commercially available Egyptian propolis on Trichomonas vaginalis. New Egypt J Med, 2007; 36(1):7-15.

Alvarez-Sánchez ME, Solano-González E, Yañez-Gómez C, Arroyo R. Negative iron regulation of the CP65 cysteine proteinase cytotoxicity in Trichomonas vaginalis. Microbes Infect, 2007; 9(1415):1597-605.

Amaral FM, Ribeiro MNS, Barbosa-Filho JM, Reis AS, Nascimento FR, Macedo RO. Plants and chemical constituents with giardicidal activity. Revista Brasileira de Farmacognosia, 2006; 16: 696-720.

Awe SO, Olajide OA, Oladiran OO, Makinde JM. Antiplasmodial and antipyretic screening of Mangifera indica extract. Phytother Res, 1998; 12(6):437-8.

Berardini N, Carle R, Schieber A. Characterization of gallotannins and benzophenone derivatives from Mango (Mangifera indica L. cv. 'Tommy Atkins') peels, pulp and kernels by high-performance liquid chromatography/electrospray ionization mass spectrometry. Rapid Commun Mass Sp, 2004; 18(19):2208-16. 
Cudmore SL, Delgaty KL, Hayward-McClelland SF, Petrin DP, Garber GE. Treatment of infections caused by metronidazole-resistant Trichomonas vaginalis. Clin Microbiol Rev, 2004; 17(4):783-93.

Cui CB, Zhao QC, Cai B, Yao XS Osadsa H. Two new and four known polyphenolics obtained as new cell-cycle inhibitors from Rubus aleaefolius Poir. J Asian Nat Prod Res, 2002; 4(4):243-52.

de Brum Vieira P, Giordani RB, Macedo AJ, Tasca T. Natural and synthetic compound anti-Trichomonas vaginalis: an update review. Parasitol Res, 2015; 114(4):1249-61.

El-Gied AAA, Joseph MR, Mahmoud IM, Abdelkareem AM, Al Hakami AM, Hamid ME. Antimicrobial activities of seed extracts of Mango (Mangifera indica L.). Adv Microbiol, 2012; 2(4):571-6.

Engels C, Gänzle MG, Schieber A. Fractionation of gallotannins from mango (Mangifera indica L.) kernels by high-speed counter-current chromatography and determination of their antibacterial activity. J Agric Food Chem, 2010; 58(2):775-80.

Engels C, Knödler M, Zhao YY, Carle R, Gänzle MG, Schieber A. Antimicrobial activity of gallotannins isolated from Mango (Mangifera indica L.) kernels. J Agric Food Chem, 2009; 57(17):7712-18.

Ezz Eldin HM, Badawy AF. In vitro anti-Trichomonas vaginalis activity of Pistacia lentiscus mastic and Ocimum basilicum essential oil. J Parasit Dis, 2015; 39(3):465-73.

Figueroa-Angulo EE, Rendón-Gandarilla FJ, Puente-Rivera J, Calla-Choque JS, Cárdenas-Guerra RE, Ortega-López J, Arroyo R. The effects of environmental factors on the virulence of Trichomonas vaginalis. Microbes Infect, 2012; 14(15):1411-27.

Gan RY, Kong KW, Li HB, Wu K, Ge YY, Chan CL, Shi $\mathrm{XM}$, Corke H. Separation, identification, and bioactivities of the main gallotannins of red sword bean (Canavalia gladiata) coats. Front Chem, 2018; 6:39.

Grabensteiner E, Liebhart D, Arshad N, Hess M. Antiprotozoal activities determined in vitro and in vivo of certain plant extracts against Histomonas meleagridis, Tetratrichomonas gallinarum and Blastocystis sp. Parasitol Res, 2008; 103(6):1257-64.

Haddock EA, Gupta RK, Al-Shafi SM, Haslam E, Magnolato D. The metabolism of gallic acid and hexahydroxydiphenic acid in plants Part 1. Introduction. Naturally occurring galloyl esters. J Chem Soc Perkin Transactions, 1982; 1:2515-24.

Hagenah S, Gross GG. Biosynthesis of 1, 2, 3, 6-tetra- $O$-galloyl$\beta$-D-glucose. Phytochemistry, 1993; 32:637-41.

Hassani S, Asghari G, Yousefi H, Kazemian A, Rafieiean M, Darani HY. Effects of different extracts of Eucalyptus camaldulensis on Trichomonas vaginalis parasite in culture medium. Adv Biomed Res, 2013; 2:47.

Ibrahim AN. Comparison of in vitro activity of metronidazole and garlic-based product (Tomex®) on Trichomonas vaginalis. Parasitol Res, 2013; 112(5):2063-7.

Innocente AM, de Brum Vieira P, Frasson AP, Casanova BB, Gosmann G, Gnoatto SCB, Tasca T. Anti-Trichomonas vaginalis activity from triterpenoid derivatives. Parasitol Res, 2014; 113(8):2933-40.

Ka buki T, Nakajima H, Arai M, Ueda S, Kuwabara Y, Dosako S. Characterization of novel antimicrobial compounds from Mango (Mangifera indica L.) kernel seeds. Food Chem, 2000; 71(1):61-6.

Kolodziej H, Kayser O, Kiderlen AF, Ito H, Hatano T, Yoshida T, Foo LY. Antileishmanial activity of hydrolyzable tannins and their modulatory effects on nitric oxide and tumour necrosis factor-alpha release in macrophages in vitro, Planta Medica, 2001; 67(09):825-32.

Lee TH, Chiou JL, Lee CK, Kuo YH. Separation and determination of chemical constituents in the roots of Rhus javanica L. var. roxburghiana. J Chin Chem Soc, 2005; 52(4):833-41.
Masibo M, He Q. Major mango polyphenols and their potential significance to human health. Compr Rev Food Sci Food Saf, 2008; 7(4):309-19.

Núñez Sellés AJ, Vélez Castro HT, Agüero-Agüero J, GonzálezGonzález J, Naddeo F, De Simone F, Rastrelli L. Isolation and quantitative analysis of phenolic antioxidants, free sugars, and polyols from mango (Mangifera indica L.) stem bark aqueous decoction used in Cuba as a nutritional supplement. J Agri Food Chem, 2002; 50(4):762-6.

Rajan S, Thirunalasundari T, Jeeva S. Anti-enteric bacterial activity and phytochemical analysis of the seed kernel extract of Mangifera indica Linnaeus against Shigella dysenteriae (Shiga, corrig.) Castellani and Chalmers. Asian Pac J of Trop Med, 2011; 4(4):294-300.

Rakholiya KD, Kaneria MJ, Chanda SV. In vitro assessment of novel antimicrobial from methanol extracts of matured seed kernel and leaf of Mangifera indica L.(Kesar Mango) for inhibition of Pseudomonas spp. and their synergistic. Am J Drug Discovery Dev, 2015; 5:13-23.

Ruiz L, Ruiz L, Maco M, Cobos M, Gutierrez-Choquevilca AL, Roumy V. Plants used by native Amazonian groups from the Nanay River (Peru) for the treatment of malaria. J Ethnopharmacol, 2011; 133(2): 917-21.

Sairam K, Hemalatha S, Kumar A, Srinivasan T, Ganesh J, Shankar M, Venkataraman S. Evaluation of anti-diarrhoeal activity in seed extracts of Mangifera indica. J Ethnopharmacol, 2003; 84(1):11-15.

Sehgal R, Goyal K, Sehgal A. Trichomoniasis and lactoferrin: future prospects. Infect Dis Obstet Gynecol, 2012; 2012:1-8.

Shabani Z, Sayadi A. The antimicrobial in vitro effects of different Mango kernel. J App Pharma Sci, 2014; 4(5):075-9.

Sharafi SM, Yousefi M, Yousefi HA, Asghari G, Darani HY In vitro effects of various plants extracts on the growth of Trichomonas vaginalis. Infect Disord Drug Targets, 2013; 13(5):322-7.

Silver BJ, Guy RJ, Kaldor JM, Jamil MS, Rumbold AR. Trichomonas vaginalis as a cause of perinatal morbidity: a systematic review and meta-analysis. Sex Trans Dis, 2014; 41(6):369-76.

Subbiya A, Mahalakshmi K, Pushpangadan S, Padmavathy K, Vivekanandan P, Sukumaran VG. Antibacterial efficacy of Mangifera indica L. kernel and Ocimum sanctum L. leaves against Enterococcus faecalis dentinal biofilm. J Conserv Dent, 2013; 16(5):454-7.

Sutcliffe S, Neace C, Magnuson NS, Reeves R, Alderete JF. Trichomonosis, a common curable STI, and prostate carcinogenesis-a proposed molecular mechanism. PLoS Pathogens, 2012; 8(8):e1002801.

Tona, L, Kambu K, Ngimbi N, Cimanga K, Vlietinck AJ. Antiamoebic and phytochemical screening of some Congolese medicinal plants. J Ethnopharmacol, 1998; 61(1):57-65.

Zirihi GN, Mambu L, Guédé-Guina F, Bodo B, Grellier P. In vitro antiplasmodial activity and cytotoxicity of 33 West African plants used for treatment of malaria. J Ethnopharmacol, 2005; 98(3):281-5.

How to cite this article:

Orabi MAA, Bayoumi SAL, Sayed HM, Huseein EAM, Khedr AIM, Hatano T. Simultaneous isolation of gallotannins and a related phenolic from Mangifera indica kernels and assessment of their anti-Trichomonas vaginalis activities. J Appl Pharm Sci, 2020; 10(03):022-038. 


\section{SUPPLEMENTARY MATERIAL}

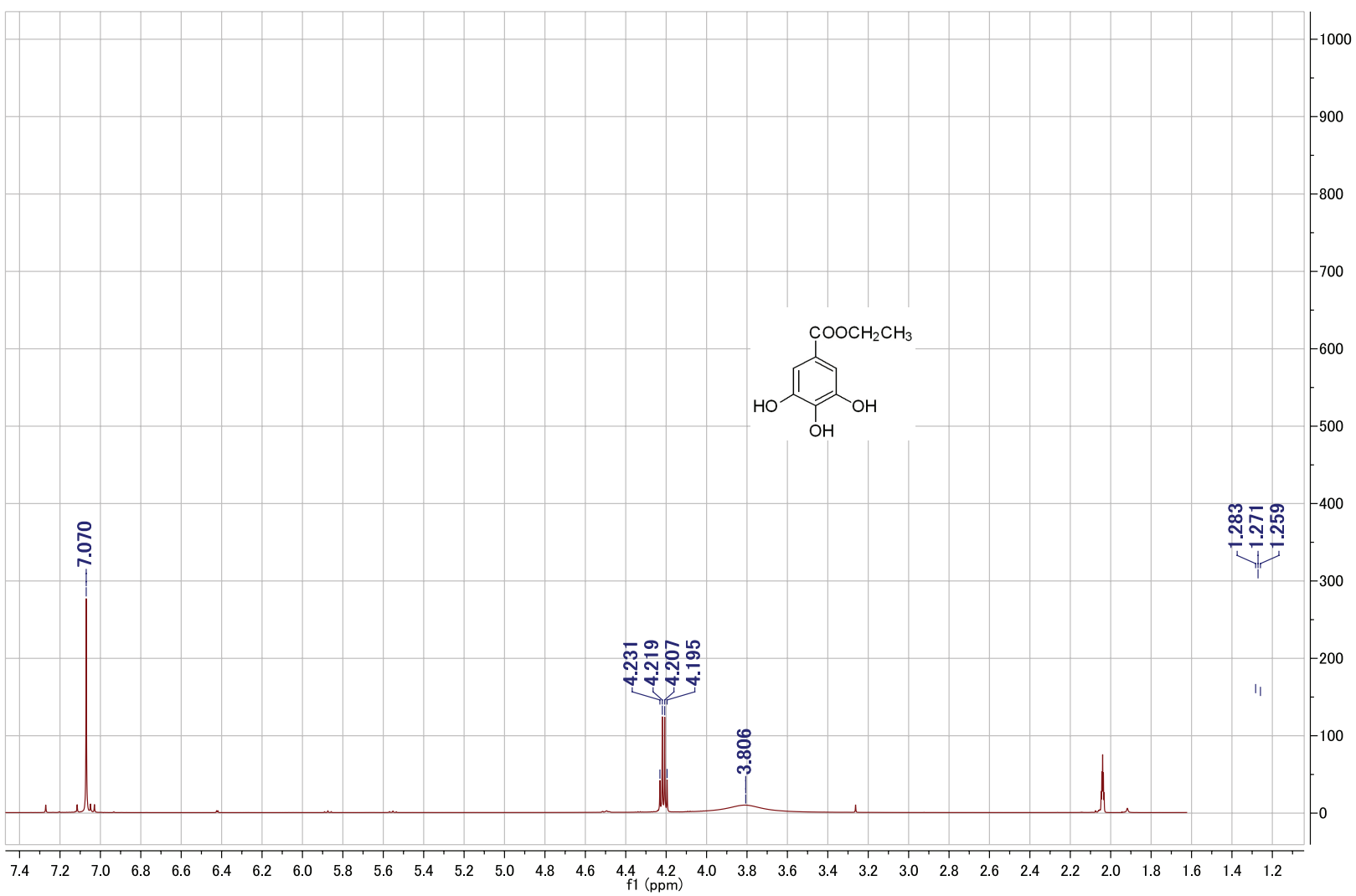

S1. ${ }^{1} \mathrm{H}$ NMR spectrum of 2 [600 MHz, (acetone- $\left.\left.d_{6}-\mathrm{D}_{2} \mathrm{O}, 9: 1\right), 27^{\circ} \mathrm{C}\right]$.

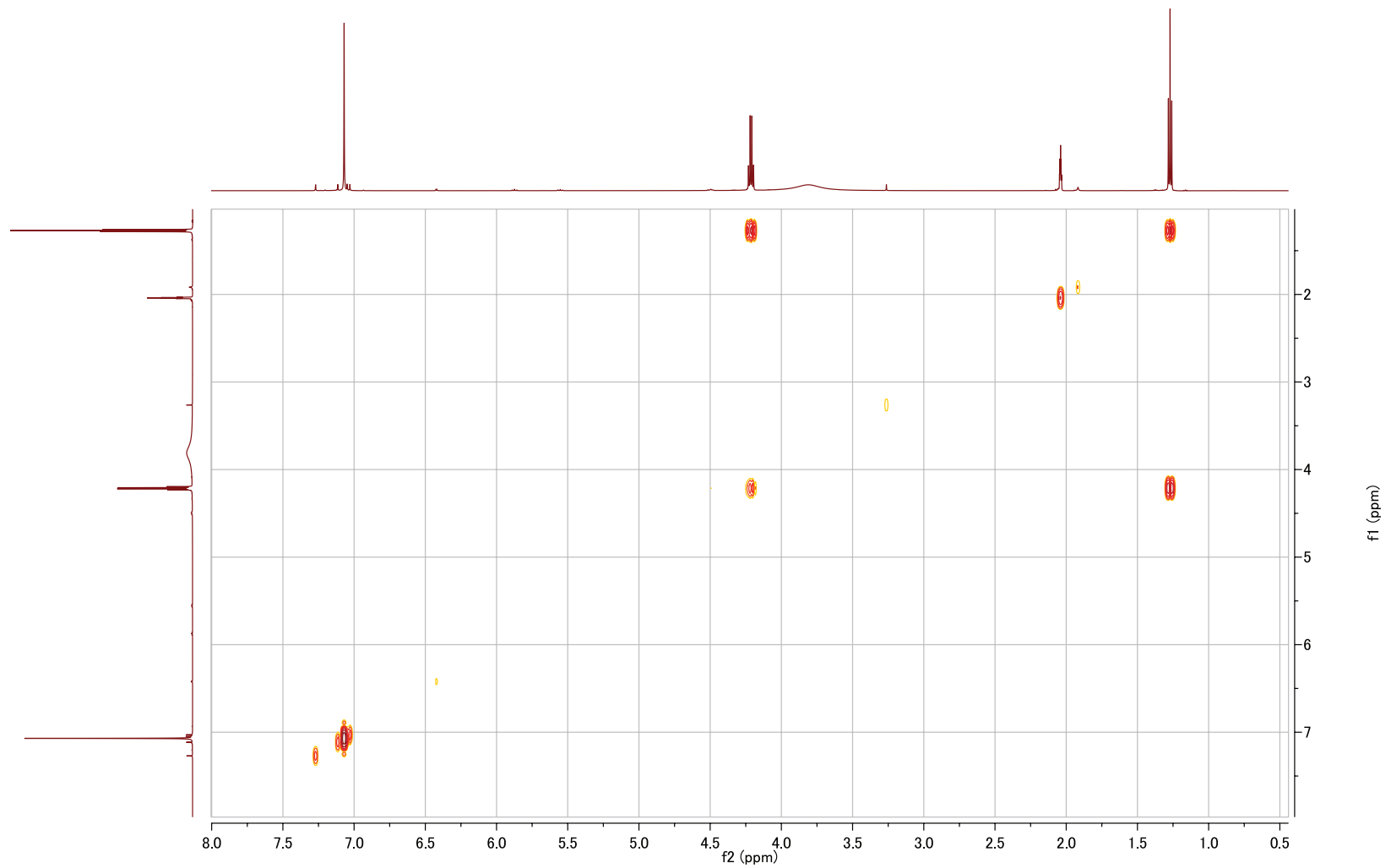

S2. ${ }^{1} \mathrm{H}-{ }^{1} \mathrm{H}$ COSY spectrum of $2\left[600 \mathrm{MHz}\right.$, (acetone- $\left.\left.d_{6}-\mathrm{D}_{2} \mathrm{O}, 9: 1\right), 27^{\circ} \mathrm{C}\right]$. 


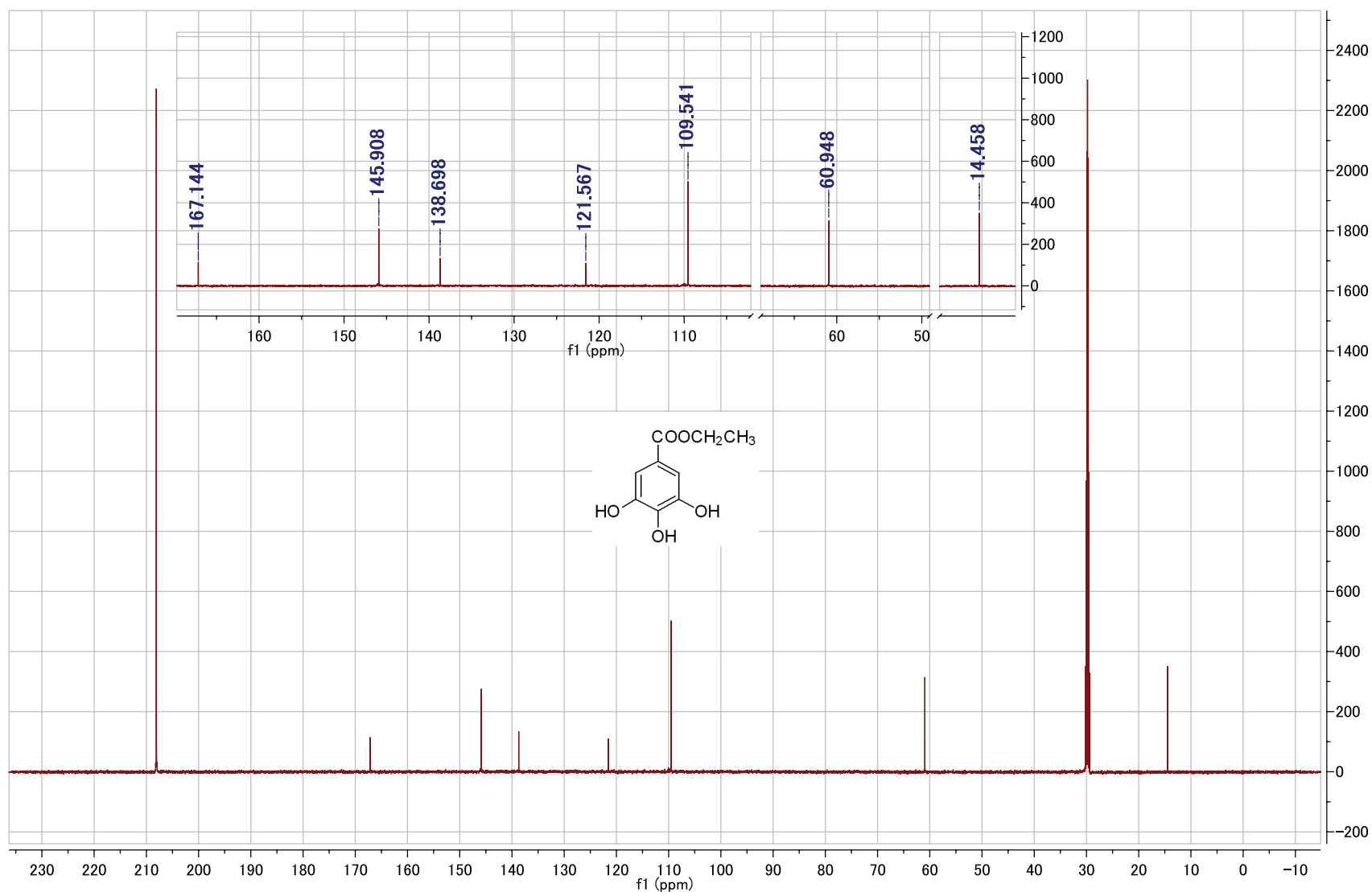

S3. ${ }^{13} \mathrm{C}$ NMR spectrum of 2 [151 MHz, (acetone- $\left.d_{6}-\mathrm{D}_{2} \mathrm{O}, 9: 1\right), 27^{\circ} \mathrm{C}$ ].

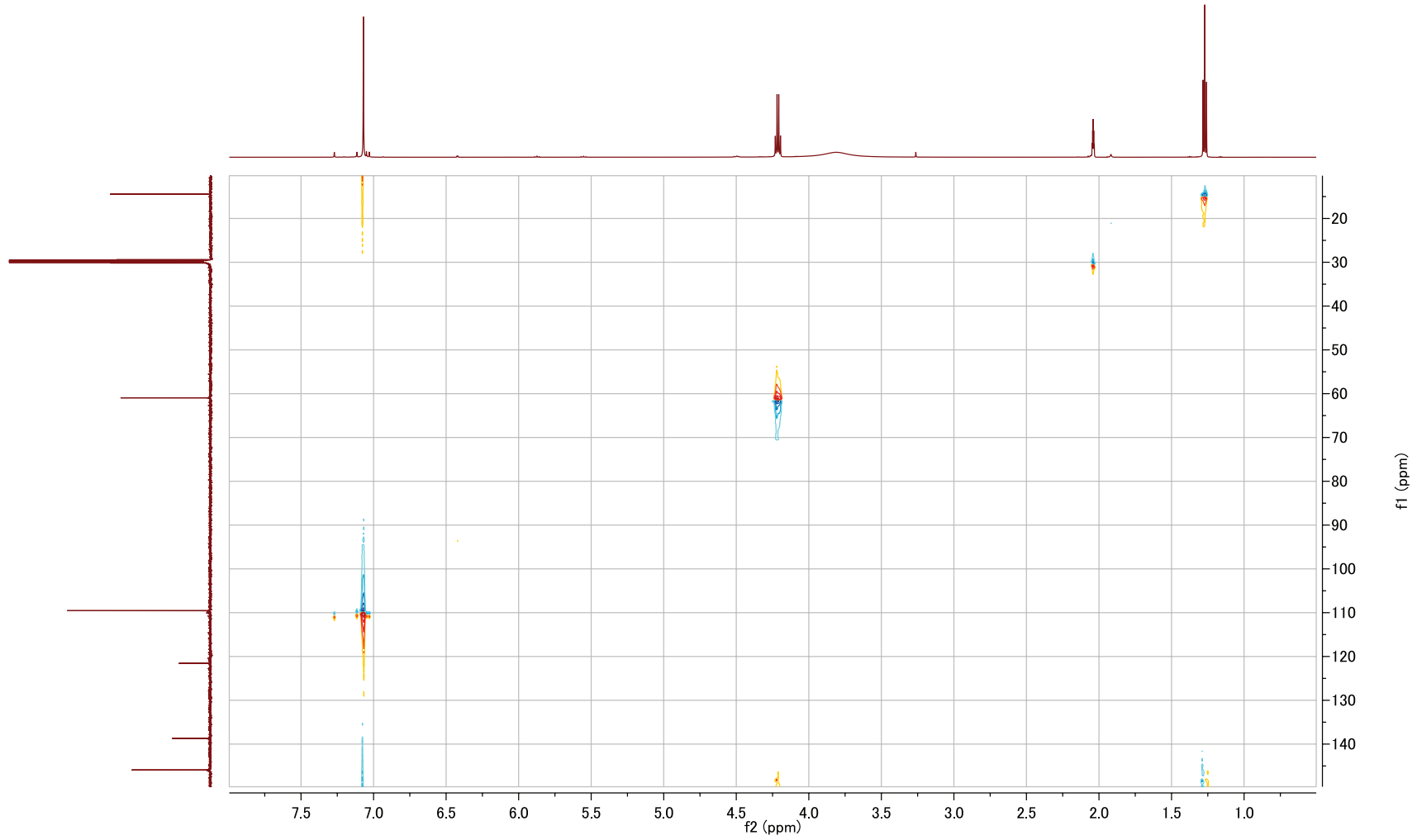

S4. HSQC spectrum of $2\left[600 \mathrm{MHz}\right.$, (acetone- $\left.\left.d_{6}-\mathrm{D}_{2} \mathrm{O}, 9: 1\right), 27^{\circ} \mathrm{C}\right]$. 


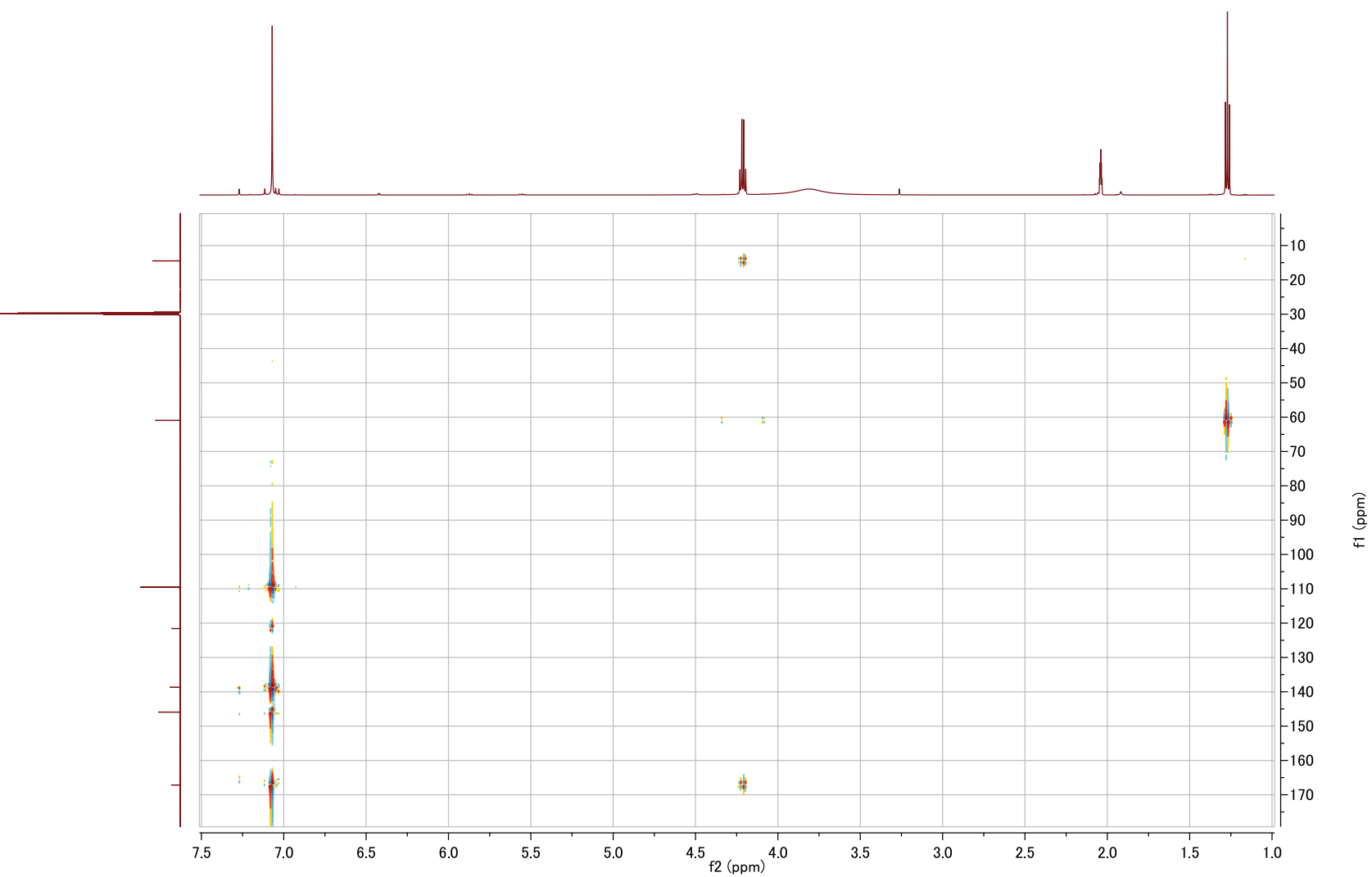

S5. HMBC spectrum of 2 [600 MHz, (acetone- $\left.\left.d_{6}-\mathrm{D}_{2} \mathrm{O}, 9: 1\right), 27^{\circ} \mathrm{C}\right]$.

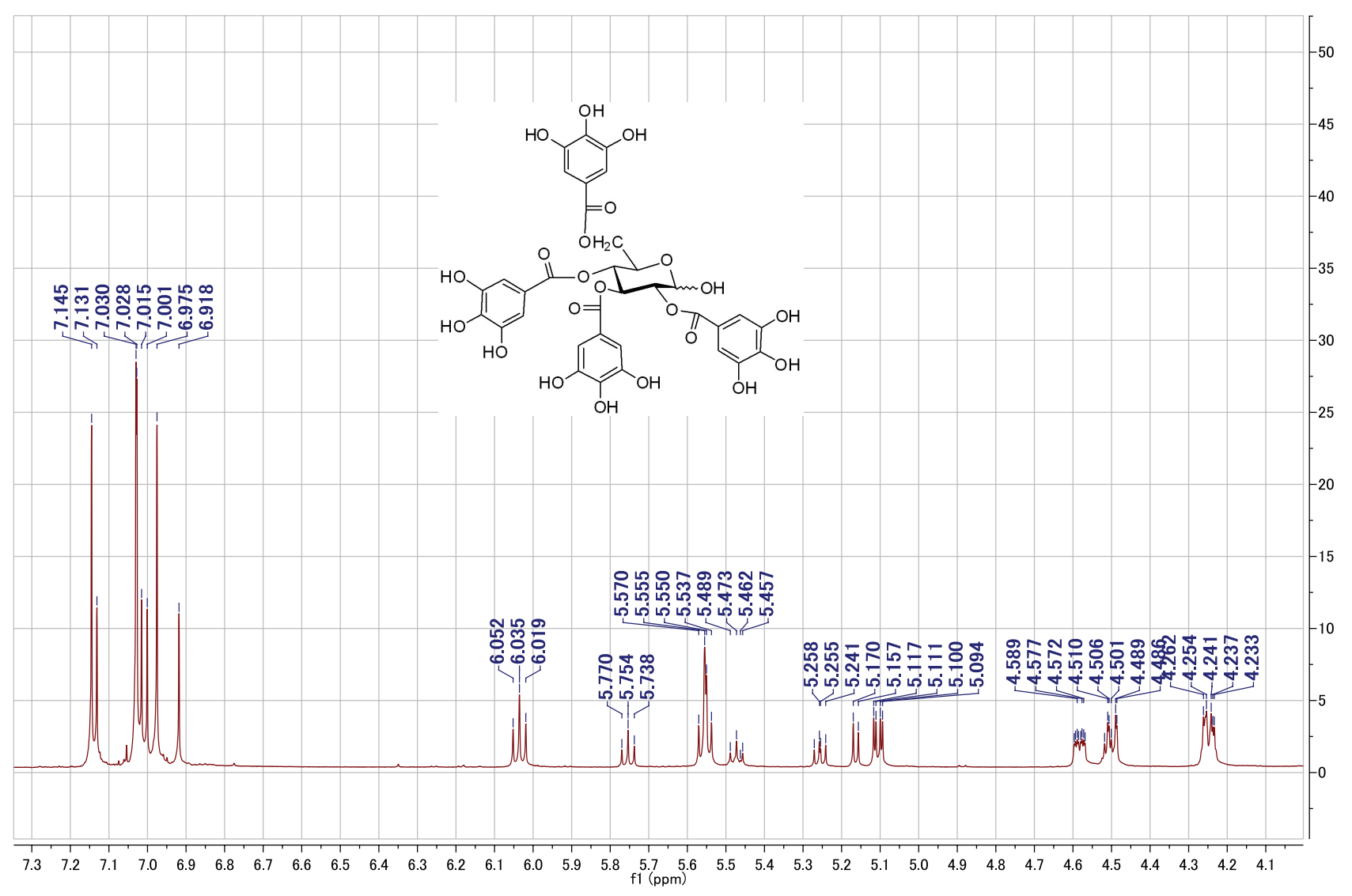

S6. ${ }^{1} \mathrm{H}$ NMR spectrum of 3 [600 MHz, (acetone- $\left.\left.d_{6}-\mathrm{D}_{2} \mathrm{O}, 9: 1\right), 27^{\circ} \mathrm{C}\right]$. 


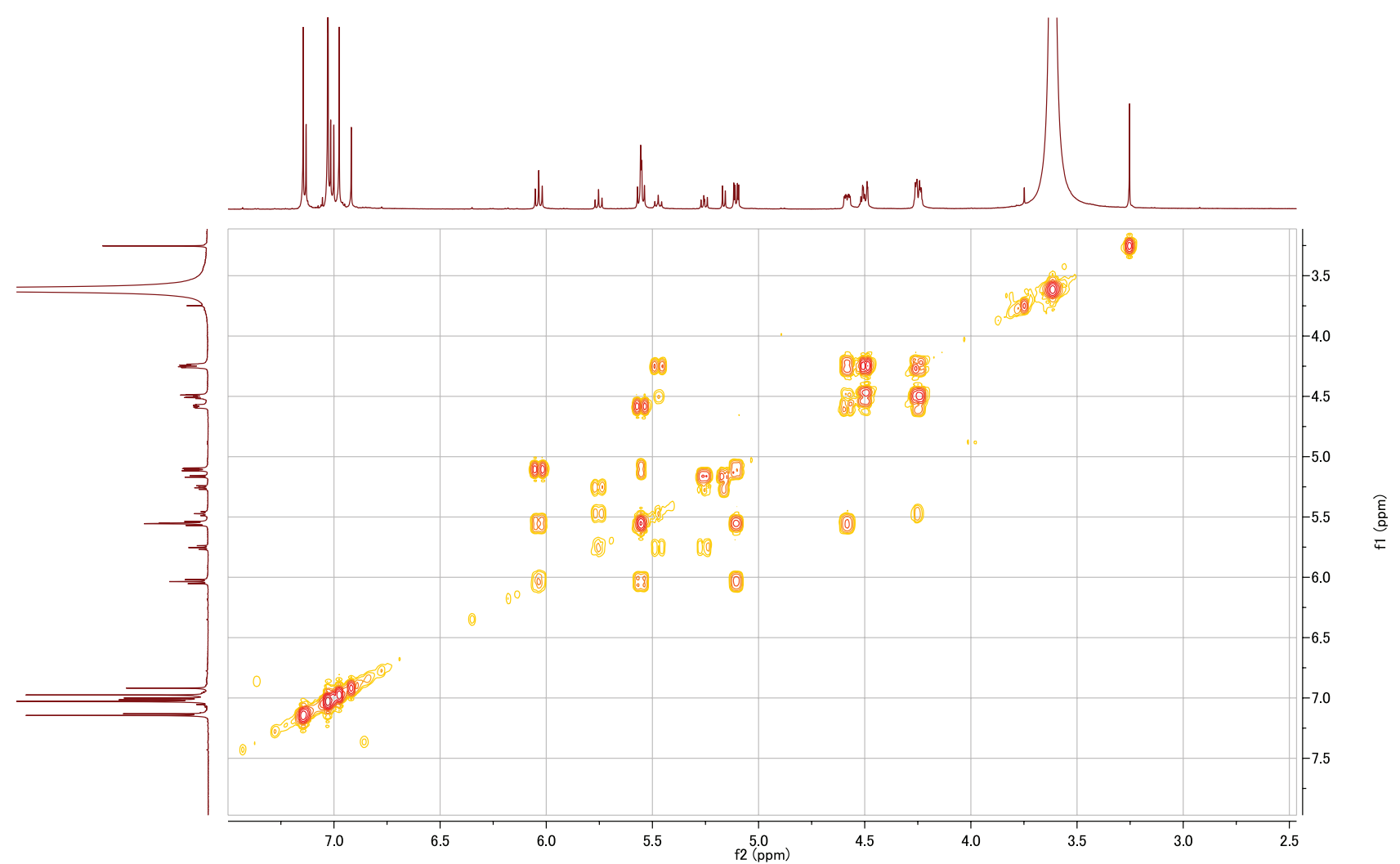

S7. ${ }^{1} \mathrm{H}-{ }^{1} \mathrm{H}$ COSY spectrum of 4 [600 MHz, (acetone- $\left.\left.d_{6}-\mathrm{D}_{2} \mathrm{O}, 9: 1\right), 27^{\circ} \mathrm{C}\right]$.

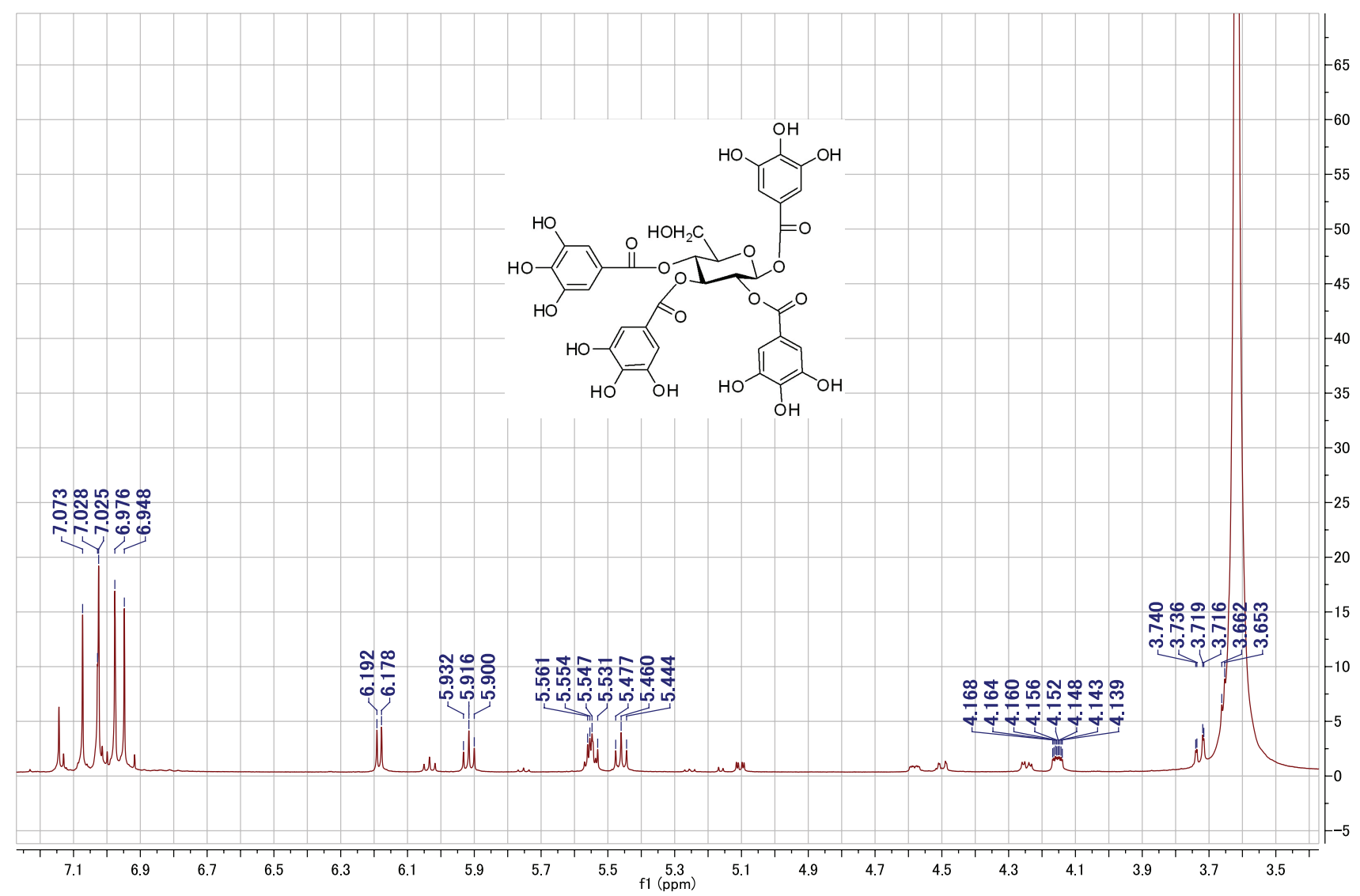

S8. ${ }^{1} \mathrm{H}$ NMR spectrum of 4 [600 MHz, (acetone- $\left.\left.d_{6}-\mathrm{D}_{2} \mathrm{O}, 9: 1\right), 27^{\circ} \mathrm{C}\right]$. 


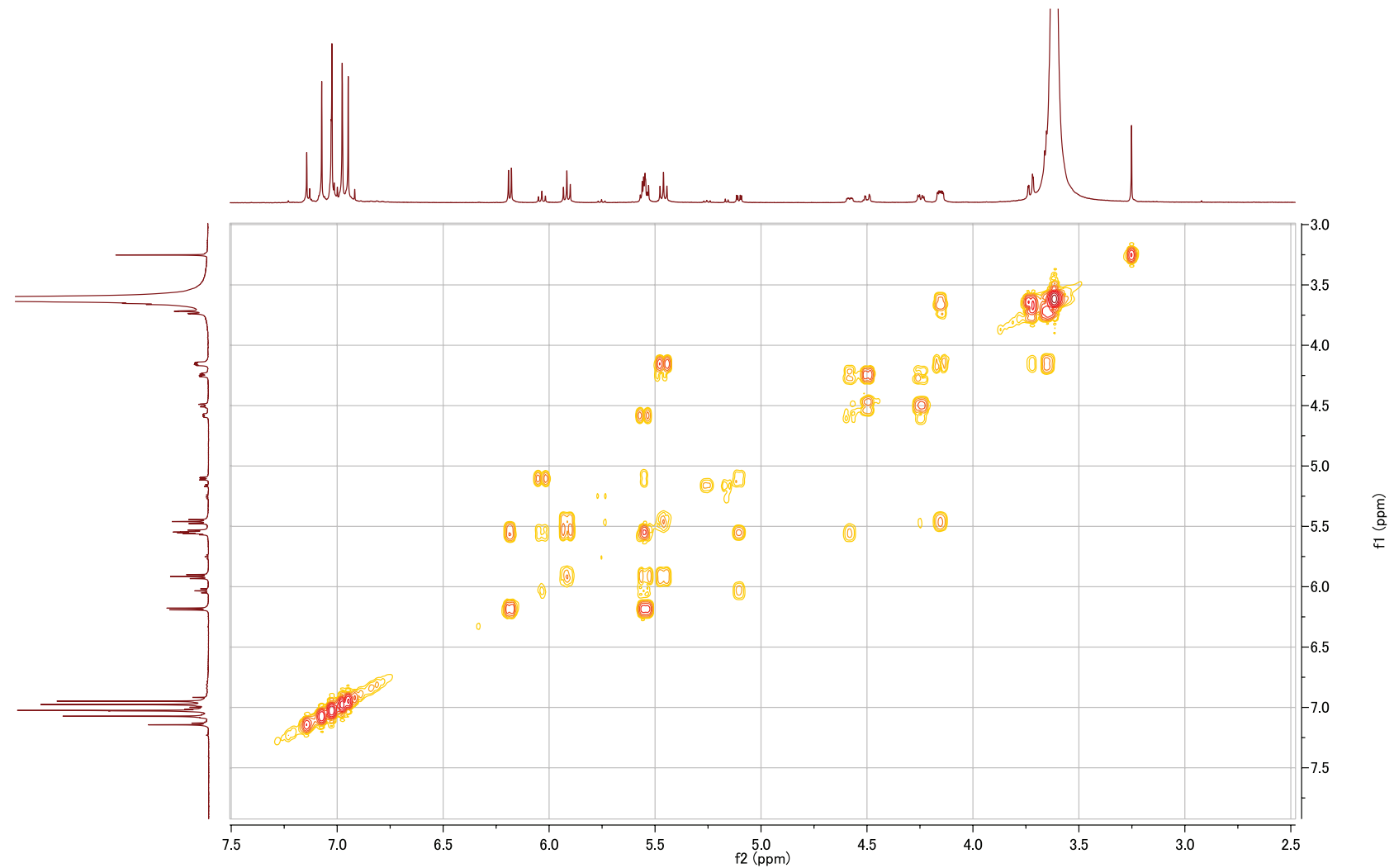

S9. ${ }^{1} \mathrm{H}-{ }^{1} \mathrm{H}$ COSY spectrum of 4 [600 MHz, (acetone- $d_{6}-\mathrm{D}_{2} \mathrm{O}, 9: 1$ ), $\left.27^{\circ} \mathrm{C}\right]$.

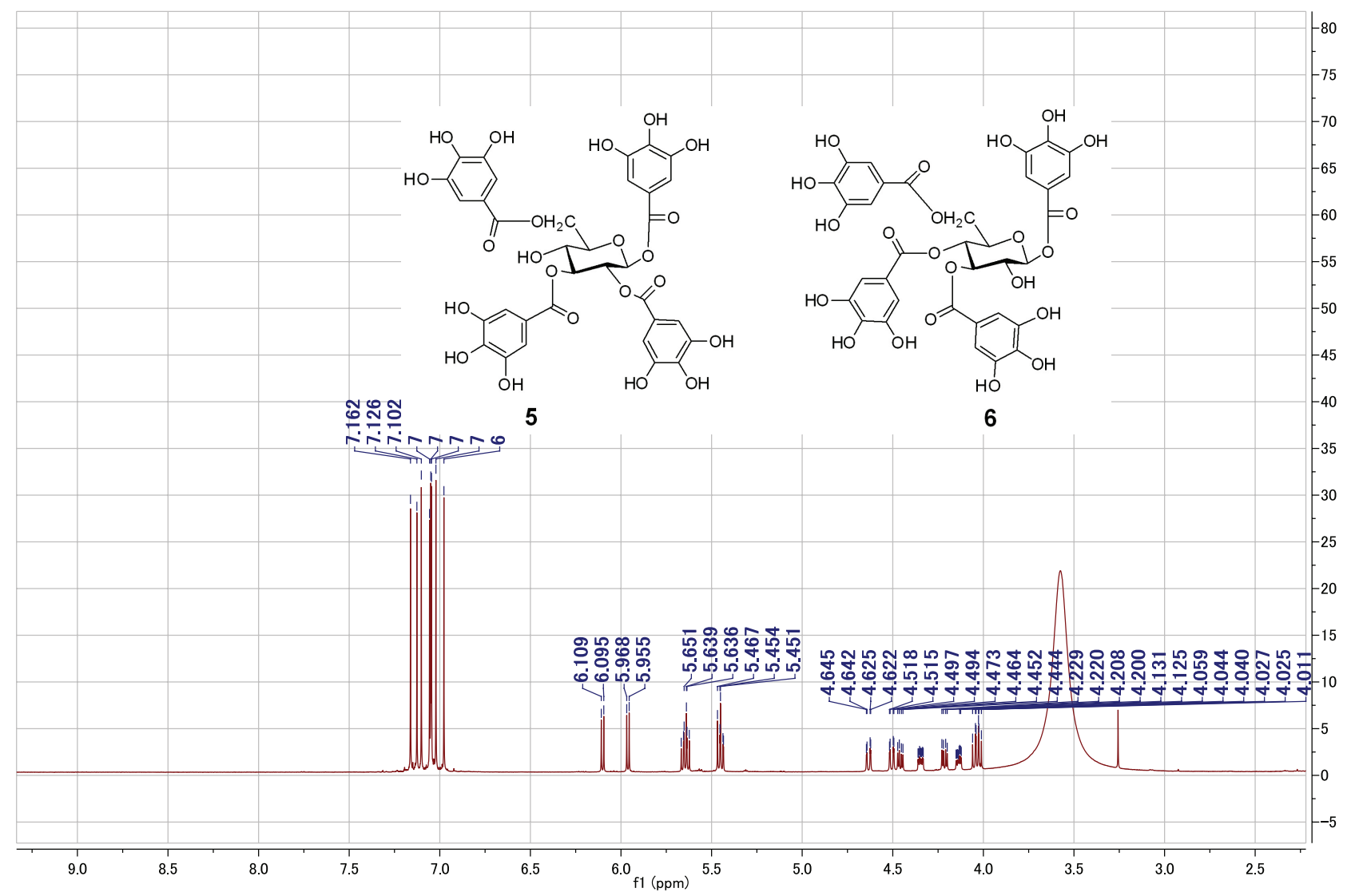

S10. ${ }^{1} \mathrm{H}$ NMR spectrum of mixture of 5 and 6 [600 MHz, (acetone- $\left.\left.d_{6}-\mathrm{D}_{2} \mathrm{O}, 9: 1\right), 27^{\circ} \mathrm{C}\right]$. 


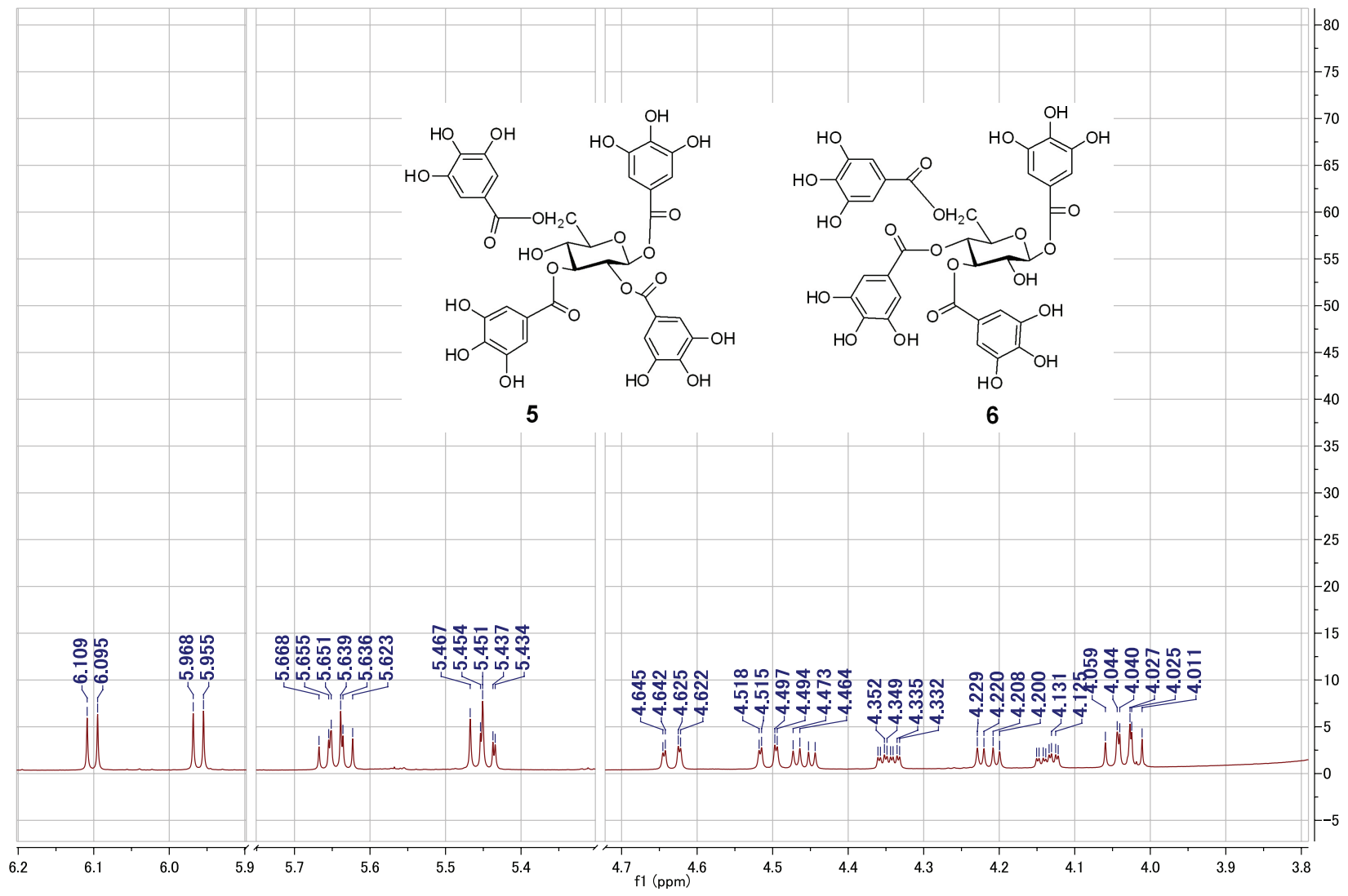

S11. Expanded sugar protons region of ${ }^{1} \mathrm{H}$ NMR spectrum of mixture of 5 and 6 [600 MHz, (acetone- $\left.\left.d_{6}-\mathrm{D}_{2} \mathrm{O}, 9: 1\right), 27{ }^{\circ} \mathrm{C}\right]$.

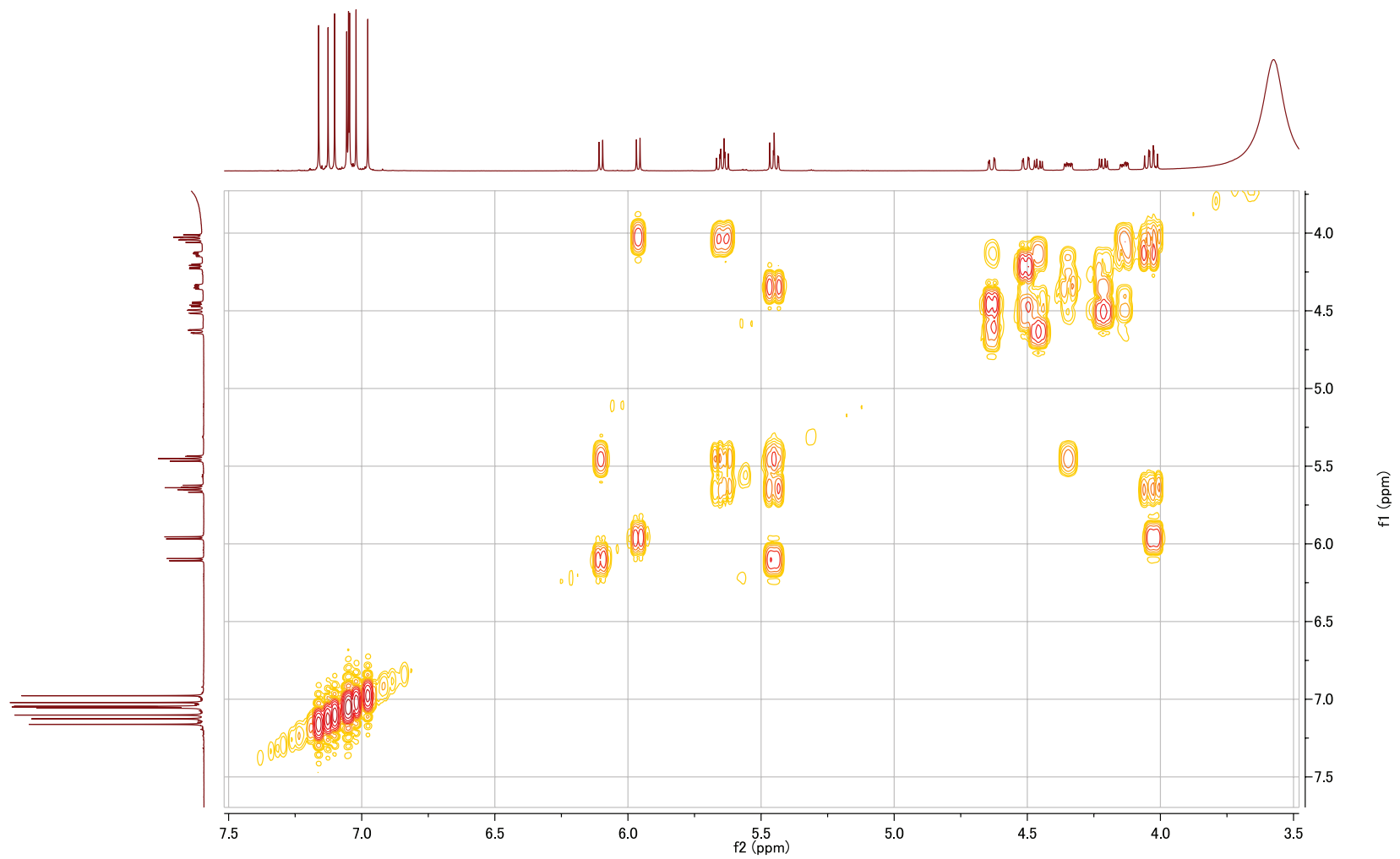

S12. ${ }^{1} \mathrm{H}-{ }^{1} \mathrm{H}$ COSY spectrum of mixture of 5 and $6\left[600 \mathrm{MHz}\right.$, (acetone- $\left.\left.d_{6} \mathrm{D}_{2} \mathrm{O}, 9: 1\right), 27{ }^{\circ} \mathrm{C}\right]$. 


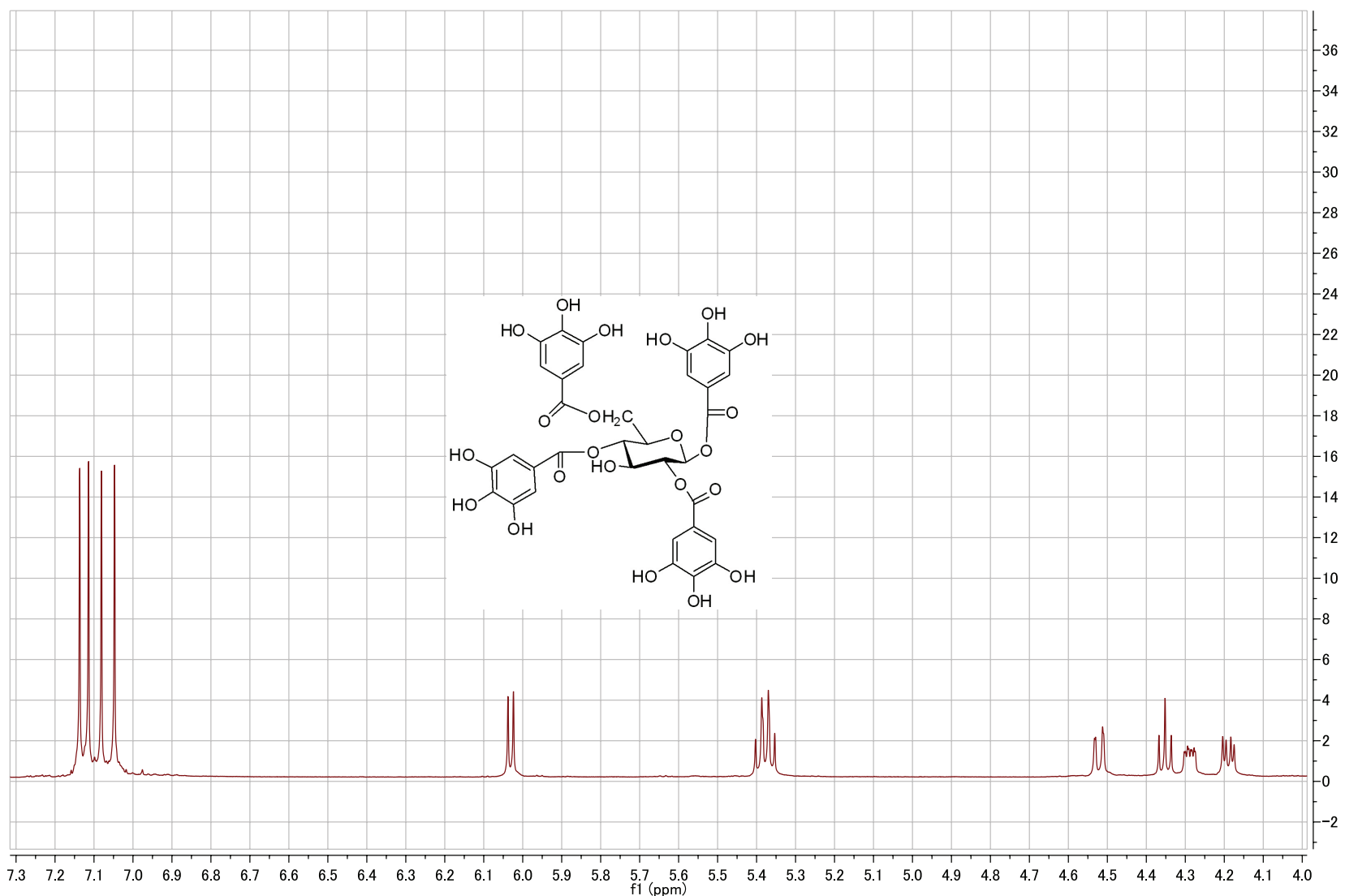

S13. ${ }^{1} \mathrm{H}$ NMR spectrum of 7 [600 MHz, (acetone- $d_{6}-\mathrm{D}_{2} \mathrm{O}, 9: 1$ ), $\left.27^{\circ} \mathrm{C}\right]$.

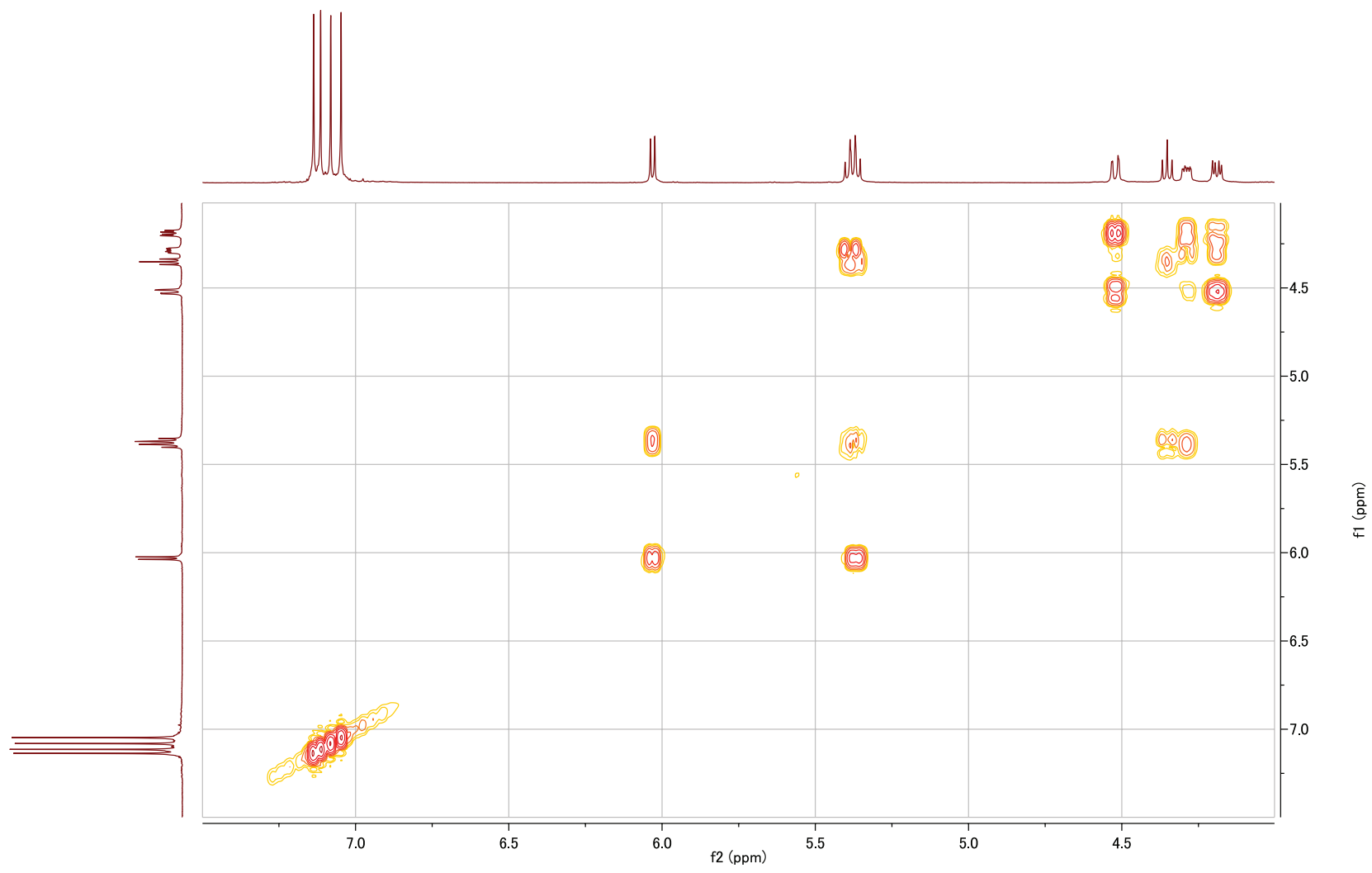

S14. ${ }^{1} \mathrm{H}-{ }^{1} \mathrm{H}$ COSY spectrum of 7 [600 MHz, (acetone- $\left.\left.d_{6}-\mathrm{D}_{2} \mathrm{O}, 9: 1\right), 27^{\circ} \mathrm{C}\right]$. 


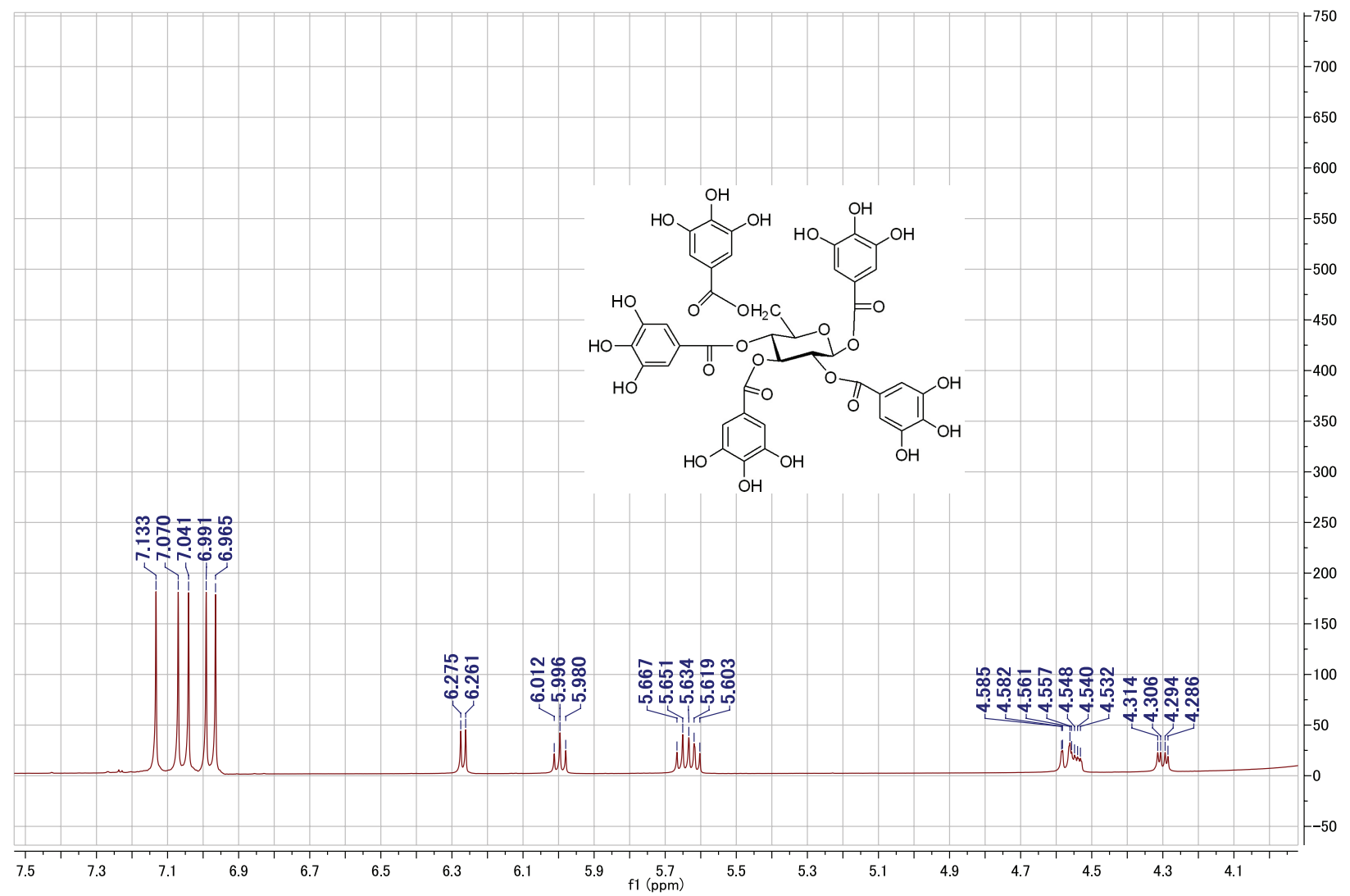

S15. ${ }^{1} \mathrm{H}$ NMR spectrum of 8 [600 MHz, (acetone- $\left.\left.d_{6}-\mathrm{D}_{2} \mathrm{O}, 9: 1\right), 27^{\circ} \mathrm{C}\right]$.

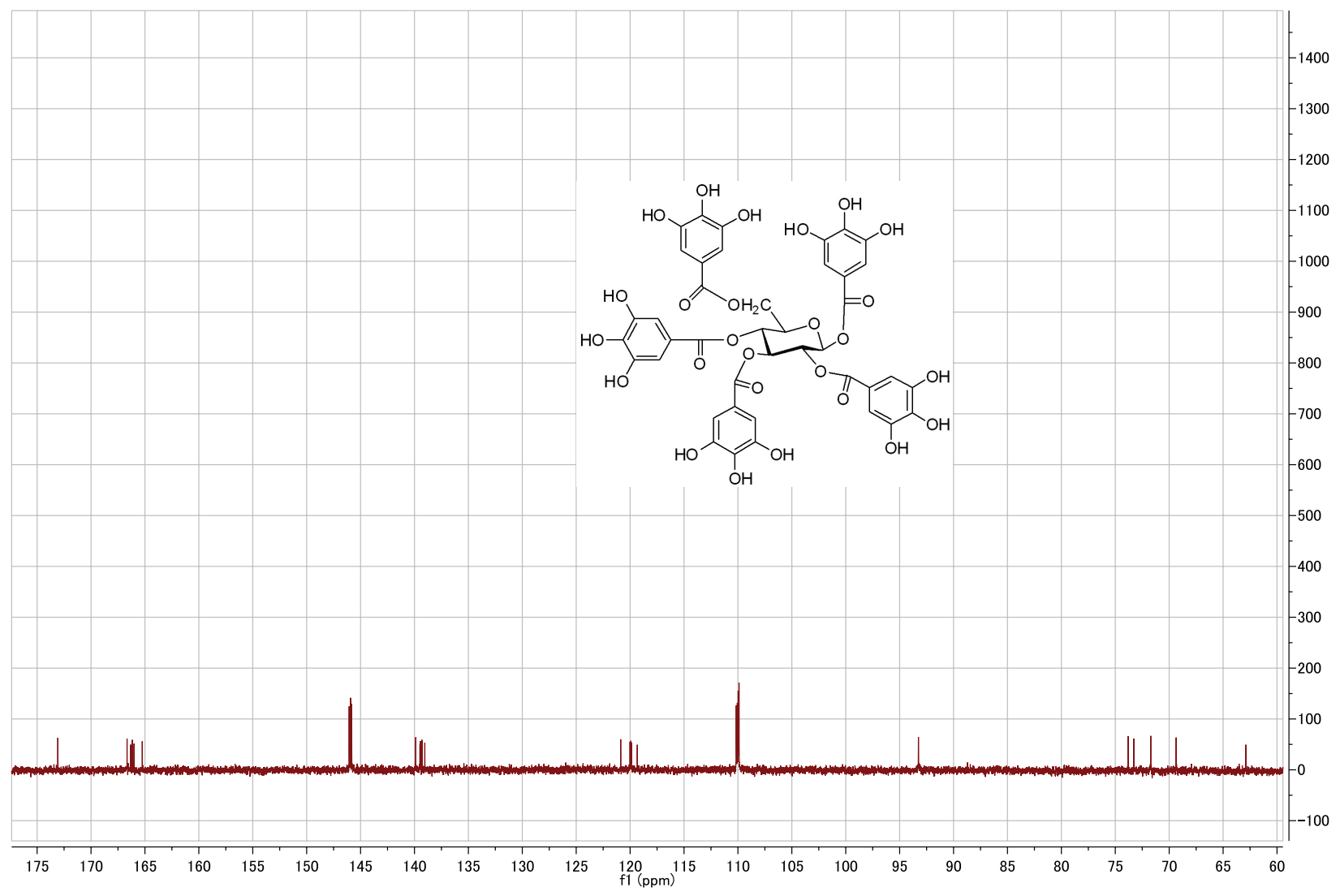

S16. ${ }^{13} \mathrm{C}$ NMR spectrum of 8 [151 MHz, (acetone- $\left.\left.d_{6}-\mathrm{D}_{2} \mathrm{O}, 9: 1\right), 27^{\circ} \mathrm{C}\right]$. 


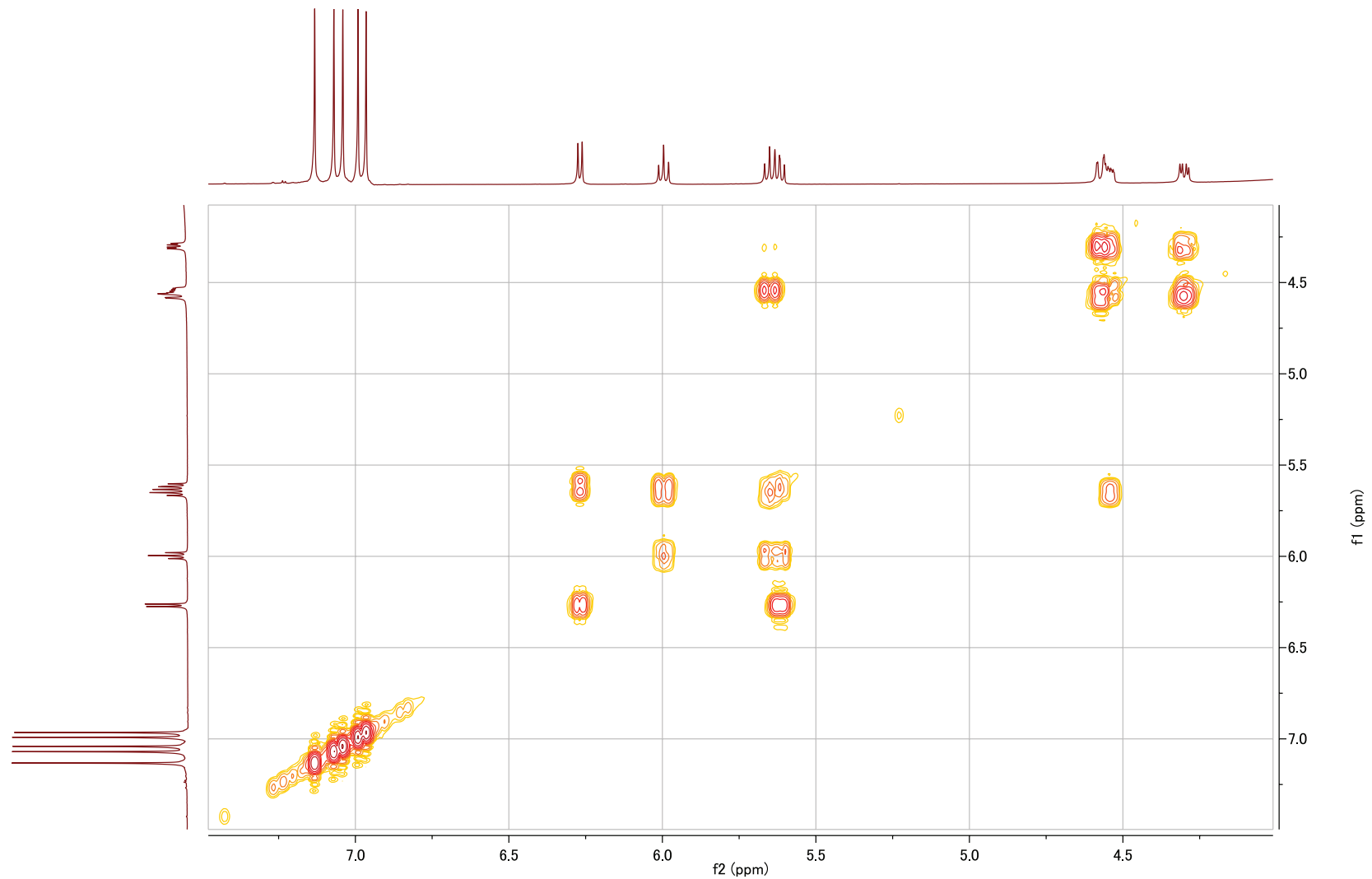

S17. ${ }^{1} \mathrm{H}-{ }^{1} \mathrm{H}$ COSY spectrum of 8 [600 MHz, (acetone- $\left.\left.d_{6}-\mathrm{D}_{2} \mathrm{O}, 9: 1\right), 27^{\circ} \mathrm{C}\right]$.

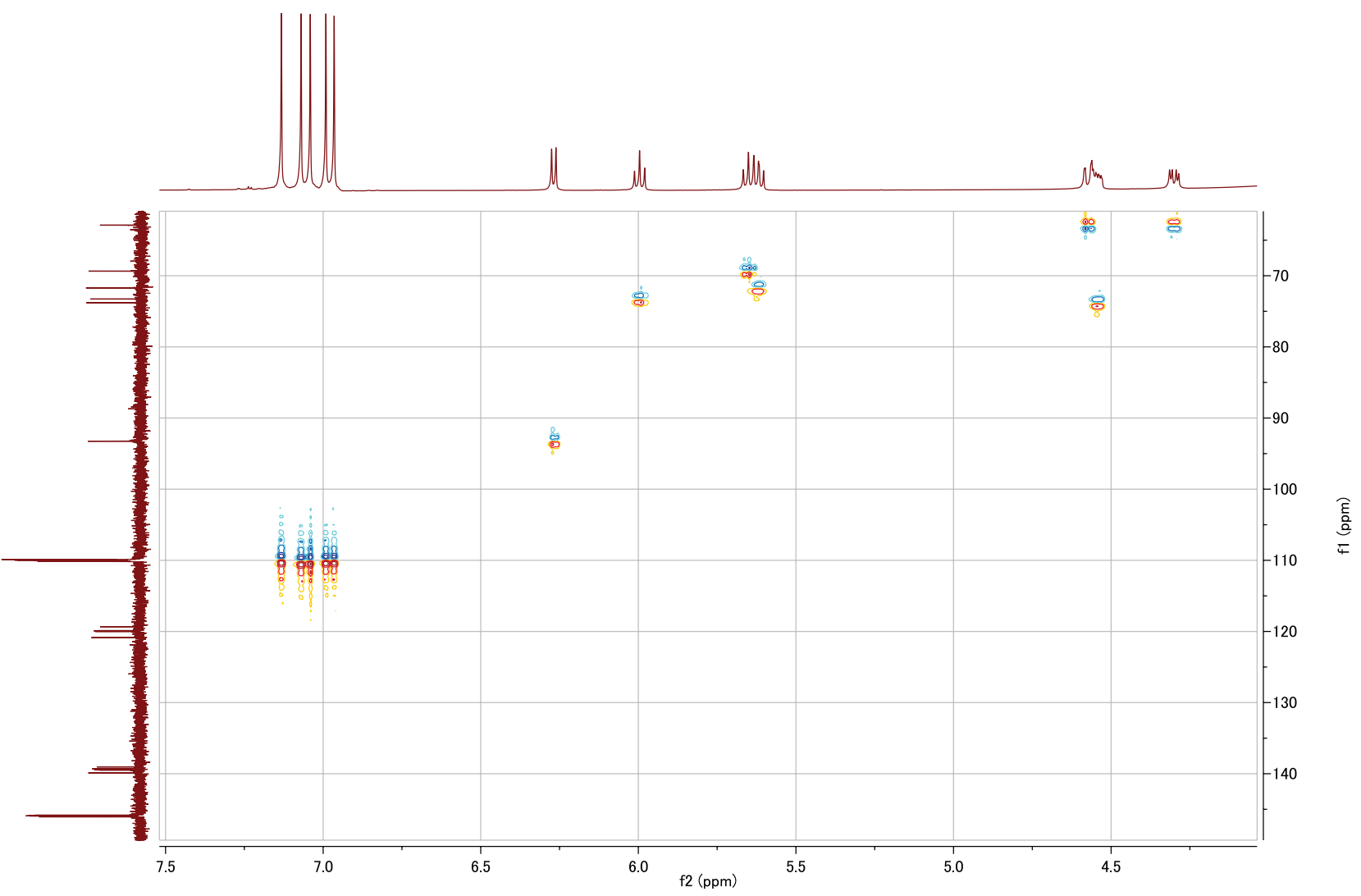

S18. HSQC spectrum of 8 [600 MHz, (acetone- $\left.\left.d_{6}-\mathrm{D}_{2} \mathrm{O}, 9: 1\right), 27^{\circ} \mathrm{C}\right]$. 


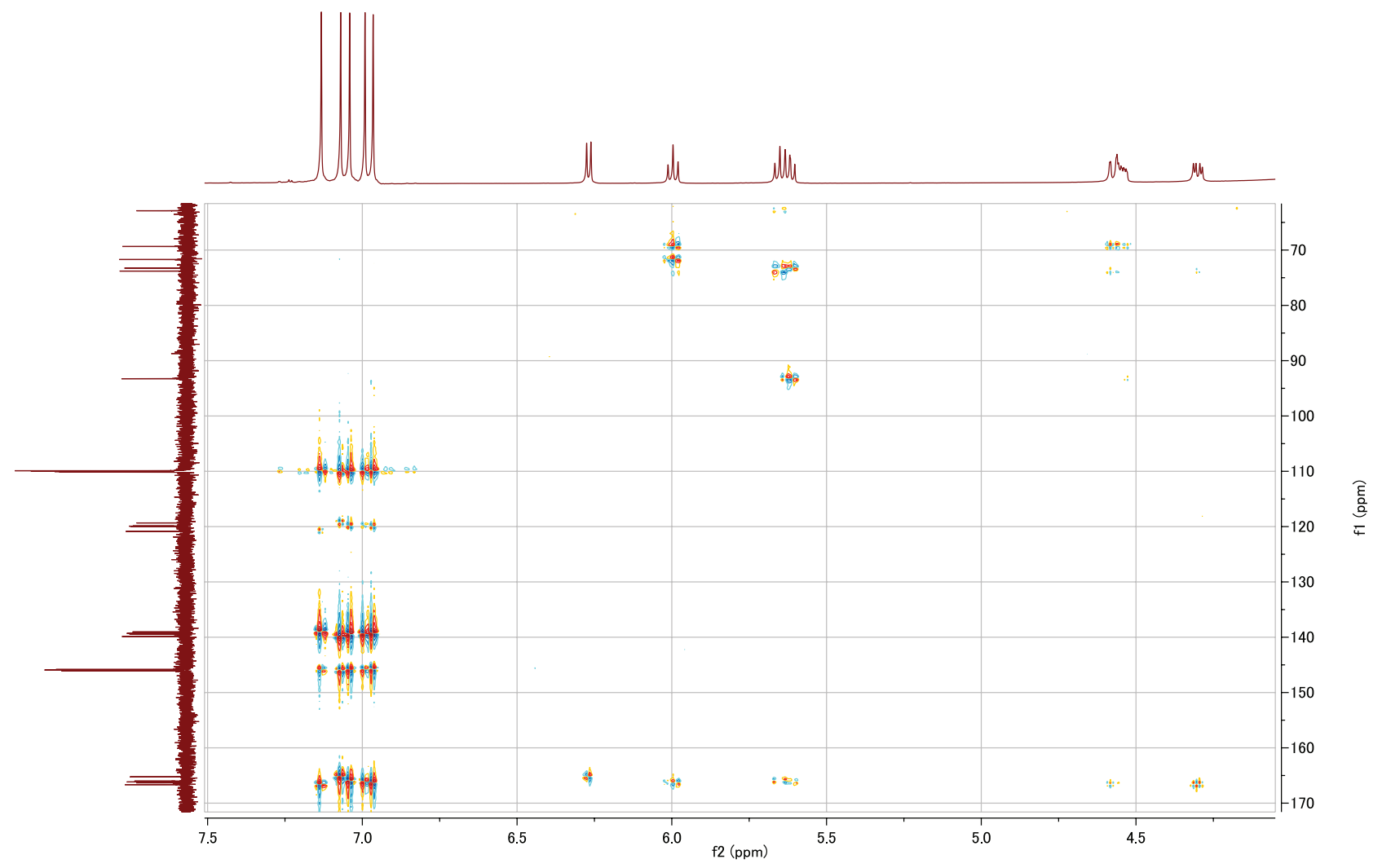

S19. HMBC spectrum of $8\left[600 \mathrm{MHz}\right.$, (acetone- $\left.\left.d_{6}-\mathrm{D}_{2} \mathrm{O}, 9: 1\right), 27^{\circ} \mathrm{C}\right]$. 